\title{
THE HISTORY AND NATURE OF THE RIGHT TO INSTITUTE A PRIVATE PROSECUTION IN SOUTH AFRICA
}

\author{
Jamil Ddamulira Mujuzi*
}

ABSTRACT

In 1828, legislation was enacted in South Africa to provide for the right to institute a private prosecution. Between 1828 and 1976, South African statutory law expressly provided that a victim of crime had a right to institute a private prosecution. However, this changed with the promulgation of the Criminal Procedure Act 51 of 1977 . Section 7 of that Act provides for a list of people who may institute private prosecutions, but it does not expressly state that a victim of crime has such a right. Nevertheless, the courts have held that section 7 does provide for the right of a victim of crime to institute a private prosecution. The purposes of this article are manifold: to highlight the history of the right to institute a private prosecution in South Africa; to argue that although section 7 does not expressly provide for the right to institute a private prosecution, its drafting history could be relied on to contend for the existence of such right; to discuss the nature of the right to institute a private prosecution; to discuss the limitations on the right to institute a private prosecution; and to suggest ways in which this right may be strengthened.

Keywords: Bill of Rights; private prosecution; South Africa; Constitution of the Republic of South Africa; legal history

* Professor of Law, Faculty of Law, University of the Western Cape. E-mail: djmujuzi@gmail.com 


\section{Introduction}

Although South African courts have, for many years, recognised that a victim of crime may institute a private prosecution, there is no express constitutional or statutory right to institute a private prosecution. Unlike in some African countries, such as Kenya and the Gambia, the Constitution of the Republic of South Africa, 1996 (hereafter the 1996 Constitution) does not mention private prosecutions. Nonetheless, for a long time, the courts have held that a victim of crime has a right to institute a private prosecution. ${ }^{1}$

Before dealing with this jurisprudence, it is important to note that, in South African law, there are two types of private prosecutions. ${ }^{2}$ First, private prosecution by an individual under section 7 of the Criminal Procedure Act 51 of 1977 (hereafter the 1977 Act) on the basis of a certificate issued by the Director of Public Prosecutions (DPP) - which is the focus of this article; and, secondly, private prosecution by statutory right under section 8 of the 1977 Act. $^{3}$ The latter type of private prosecution can be undertaken by both natural and juristic persons on the basis of specific pieces of legislation, and requires no certificate from the DPP. ${ }^{4}$ In such a case, the DPP withdraws his right to prosecute and allows a statutory body or an individual to prosecute certain offences. Municipalities, for example, may prosecute people or

1 In the past, however, private prosecutions were resorted to by employers to prosecute employees for conduct, such as absence from work or leaving the employer's premises without permission. See, for example, Cuppa Gownden (Appellants) v Hawksworth (Respondent) (1896) 17 NLR 340; Himunchal v Rojia (1904) 25 NLR 259; The King v Levey (1905) 19 EDC 167; Levey v Bayes 1905 EDL 167; Thoppaya $v$ Kynochs, Ltd (1923) 44 NPD 341.

2 In Rexv Kupeka 1929 OPD 65 at 66, the court gave the following two types of private prosecutions, namely "[e]very person having the necessary interest may bring a private prosecution on obtaining a nolle prosequi from the Attorney-General, and some municipalities and other public bodies are statutorily empowered to bring private prosecutions for contraventions of their regulations without having to obtain a nolle prosequi".

3 Section 8 provides that "(1) [a]ny body upon which or person upon whom the right to prosecute in respect of any offence is expressly conferred by law, may institute and conduct a prosecution in respect of such offence in any court competent to try that offence. (2) A body which or a person who intends exercising a right of prosecution under subsection (1), shall exercise such right only after consultation with the attorney general [DPP] concerned and after the attorney-general [DPP] has withdrawn his right of prosecution in respect of any specified offence or any specified class or category of offences with reference to which such body or person may by law exercise such right of prosecution. (3) An attorney-general [DPP] may, under subsection (2), withdraw his right of prosecution on such conditions as he may deem fit, including a condition that the appointment by such body or person of a prosecutor to conduct the prosecution in question shall be subject to the approval of the attorney-general [DPP], and that the attorney-general [DPP] may at any time exercise with reference to any such prosecution any power which he might have exercised if he had not withdrawn his right of prosecution". In Germiston Town Council v Union Government 1931 TPD 396 at 402, the court held that the right of municipalities to institute private prosecutions was granted by the legislature.

4 See, for example, s 23(4) of the Extension of Security of Tenure Act 62 of 1997; s 33 of the National Environmental Management Act 107 of 1998; s 24 of the Foodstuffs, Cosmetics and Disinfectants Act 54 of 1972; and s 25 of the Hazardous Substances Act 15 of 1973. 
companies for infringing municipal laws/regulations on the basis of the right granted to them under section $8 .^{5}$

This article focuses on the right to institute a private prosecution on the basis of a certificate issued by the DPP after he has declined to prosecute. Below, the author discusses the history of the right to institute a private prosecution in South Africa.

\section{The history of private prosecutions in South African law}

Private prosecutions were introduced in South Africa by the British colonialists. In Groenewoud and Colyn v Innesdale Municipality, ${ }^{6}$ the court held that:

There can be no doubt that under Roman-Dutch law, more especially after the Criminal Ordinance of 5th July, 1570, the right of prosecution vested solely in the State. This was recognised in various statutory enactments in the Cape, and the whole subject was fully dealt with in the Criminal Procedure Ordinance No. 40 of 1828, the provisions of which upon the question of prosecution were reproduced in the Transvaal by Law 9 of 1866 and in the Criminal Procedure Code No. 1 of 1903. These Ordinances provide that the only persons entitled to prosecute privately are those who can show some substantial and peculiar interest in the issue of the trial arising out of some injury which they have suffered by the commission of the alleged offence. ${ }^{7}$

The court added that " $[t]$ here is no doubt that the right of private prosecution is a matter appertaining, generally speaking, to the administration of justice". ${ }^{8}$ In Mullins and Meyer $v$ Pearlman, ${ }^{9}$ the court held that "[t]he right of private prosecution for criminal offences in South Africa is apparently the creature of statute. It did not exist under Roman-Dutch law so far as I am aware". ${ }^{10}$ In England, the right to institute

5 There is a long list of cases dating back to 1884 in which statutory bodies have prosecuted individuals or companies. See Benoni Municipality v Jungi Ragnana 1956 (3) SA 513 (T). For a detailed discussion of this aspect, see National Society for the Prevention of Cruelty to Animals $v$ Minister of Justice and Constitutional Development (Corruption Watch as amicus curiae) 2017 (4) BCLR 517 (CC). However, a decision by a municipality to conduct a private prosecution has to be authorised by the relevant officials or committee; if not, the prosecution is invalid. See Woolf $v$ Rex 1911 EDL 119.

6 Groenewoud and Colyn v Innesdale Municipality 1915 TPD 413.

7 Idem at 415 .

8 Ibid.

9 Mullins and Meyer v Pearlman 1917 TPD 639.

10 Idem at 643. See, also, Eaton v Moller (1871-1872) 2 Roscoe 85 at 86, in which Denyssen J of the Supreme Court of the Cape of Good Hope held that "as the law at one time stood, no one but the Fiscal or Attorney-General could prosecute criminally, because the object of a criminal prosecution was to vindicate the law of the country. Later that law was modified, and private parties were allowed to prosecute, on getting a certificate from the Attorney-General that he declined to do so. Later still there arose another modification, by which the private party was allowed to elect whether he himself would prosecute or would put the matter into the hands of the Public Prosecutor". 
private prosecutions preceded public prosecutions. One of the things that the British introduced to the Cape was English criminal procedure law. The British settlers found the legal system at the Cape (Roman-Dutch law) unfamiliar and wanted English law to be introduced. ${ }^{11}$ The introduction of British law to the Cape was preceded by a commission of inquiry. The debates of the British Parliament (House of Commons) show that the legislators at the time wanted that commission to be established with the mandate to, inter alia, look "into the state of the laws; and also into the practical administration of justice". ${ }^{12}$ When the commission of inquiry (the Colebrooke and Bigge Commission) was established, it was indeed given than mandate and ${ }^{13}$ one of the issues it dealt with concerned the prosecution of offences. The commission recommended that:

\footnotetext{
The prosecution of crimes and misdemeanors throughout the Colony should be effected by informations filed by the Attorney General in cases of importance, and by the clerks of the Crown in his name in ordinary cases, but we think that in all others, but more especially in those of libel, assault, or other misdemeanors, a right should be to the parties conceiving themselves injured to carry on the prosecution themselves if they should prefer doing so, or if the Attorney General should decline it, and in such case we think that the parties declaring that intention should be required to enter into recognizances to prosecute at the next ensuing Court of Session or Circuit. ${ }^{14}$
}

On the issue of the costs in the case of an unsuccessful prosecution, the report recommended that the practice of ordering the accused, in a public prosecution, to pay "costs which their criminal conduct has occasioned" should be discontinued, but that courts should have the discretion "to order payment of costs in those cases in which private individuals having exercised the right of prosecution shall not succeed in obtaining convictions". ${ }^{15}$

The following are some of the issues that should be noted about the commission's above-mentioned recommendations regarding whether or not private prosecutions in the Colony of the Cape of Good Hope should be permitted. First, the general rule was that an offence should be prosecuted by the public prosecutor. Private prosecution was the exception. Secondly, if private prosecutions were to be allowed, it had to be limited to minor offences, such as libel and assault. Thirdly, a person had a right to institute a private prosecution, provided that he could show that he had been injured by the crime. Put differently, he had to have been a victim of crime. Fourthly, a victim of crime had a right to institute a private prosecution if he preferred to do so

11 Van den Bergh 2012: 74

12 Hansard UK House of Commons Debates no 7 (25 Jul 1822) col 1801 available at https://api. parliament.uk/historic-hansard/commons/1822/jul/25/commission-of-inquiry (accessed $11 \mathrm{Apr}$ 2019).

13 The commission was established in 1823; see Van Niekerk 2015: 379-384.

14 Theal 1897: 124-125.

15 Idem at 129. 
or if the Attorney-General had declined to prosecute. This meant that there were two ways through which a victim of crime could exercise his right to institute a private prosecution: (1) if he preferred to institute a private prosecution before the AttorneyGeneral declined to prosecute; or (2) if that person preferred to institute a private prosecution after the Attorney-General had declined to prosecute. In both cases, the Attorney-General's consent would not be a prerequisite. Fifthly, the moment the person indicated his intention to institute a private prosecution, he had to be prepared to prosecute the suspect at the next court session. This meant that a prosecution had to be conducted as soon as possible. Sixthly, in the event of an unsuccessful private prosecution, the court had the power to order the private prosecutor to reimburse the government the costs occasioned by his prosecution. The report was silent on the issue of whether some of that money would have gone to the acquitted individual. It was also silent on the question of whether, in the event of a successful prosecution, the private prosecutor was entitled to claim from the government the money he had spent on prosecuting the offender after the Attorney-General's decision to decline to prosecute.

The commission of inquiry's report was submitted to the Committee of the Legislative Council on the Judicial Establishment of the Colony of the Cape of Good Hope and was considered by the Secretary of State for War and the Colonies (Viscount Goderich). In his despatch to the Governor of the Cape (Major-General Bourke) dated 5 August 1827, Viscount Goderich expressed his views on the commissioners' report. On the issue of prosecution, Goderich noted that:

The subject of the administration of Criminal Justice is passed over by the Commissioners in their report without any particular remark. I presume it to have been their intention to dispose of this question by their general advice respecting the introduction of the Law of England... But the difficulty of adopting the English forms of practice of Criminal Procedure at the Cape of Good Hope would for the present at least appear insuperable. The great peculiarity of the English Criminal Jurisprudence is that there is no officer to whom the constitution has committed the general duty of Public Prosecutor. That Office is sustained by the Attorney General in England only in certain special cases of crimes committed directly against the state. But even in State Offences amounting to felony or treason, the Attorney General cannot subject any man to trial without the intervention of the Grand Jury. In all ordinary cases of crime Offenders are usually prosecuted by the private person more immediately injured by the Offender. Without pausing to discuss the abstract and general question whether the Office of the Public Prosecutor should in any Country be entrusted to the voluntary zeal of private persons, it is sufficient for the present purpose to say, that some more perfect security for the due execution of the Law is required at the Colony of the Cape of Good Hope. It is obvious that the great mass of the Inhabitants cannot have either leisure or inclination for such a charge, and that the participation of private men in prosecutions would be regarded, not as the assertion of an important, but only as an unrequited and invidious burthen. It is further to be considered that this peculiar principle of English Law supposes the existence of a numerous Magistracy dispersed throughout every part of the Kingdom, to whom the private prosecutor can at all times resort with little inconvenience. It requires also a large 
body of inferior Officers of Justice under the immediate command of the Magistrates. Now this complex machinery is not at present to be found in the Colony, nor have I any ground to suppose that the necessary materials from which it might be constructed could be found there. ${ }^{16}$

This despatch, to which the Royal Charter for the Better and More Effectual Administration of Justice within the Colony of the Cape of Good Hope was appended, was meant to inform the governor of the British government's position on the aspects raised by the commission. In the above quote, Goderich took the view that the system of private prosecutions as understood and applied in England at the time would not be transplanted to the Cape of Good Hope. This is because there was no "complex machinery" at the Cape of Good Hope to enable the system to function. It was also clear that the office of the public prosecutor at the Cape of Good Hope would be established with the duty to prosecute crimes. Therefore, prior to the 1828 Ordinance mentioned above, victims of crime in the Cape of Good Hope did not have a right to institute a private prosecution. This position would influence the nature of private prosecutions in South Africa for many decades to come.

Although the 1827 despatch was sceptical about allowing private prosecutions at the Cape, such prosecutions were nevertheless introduced a year later. The 1828 Ordinance on criminal procedure, ${ }^{17}$ which "adopted English criminal procedure", ${ }^{18}$ made it clear that, in all cases, it was the public prosecutor who had the right to prosecute, and that it was only when he had decided to decline to exercise that right, that he was to issue a certificate authorising a private individual to institute a private prosecution. The first sections of the Ordinance provided for the jurisdiction of the Supreme Court of the Colony of the Cape of Good Hope and for that of the inferior courts. ${ }^{19}$ Section 6 provided that " $[t]$ he Attorney-General of the Cape of Good Hope is vested with the right, and entrusted with the duty, of Prosecuting in the Name and on the Behalf of the King, all Crimes and Offences committed in this Colony". The section added that the Attorney-General had to exercise "this right of Prosecution" in person in the Supreme Court and in the lower courts through other officials, such as the clerks (in district courts), the Superintendent of Police (in the police court) or by any other person appointed by the Attorney-General. Section 8 provided that: "This right and power of Prosecution in the Attorney-General, is absolutely under his own management and control." Under section 9, the Attorney-General had "the power at any time before Conviction, of stopping all Prosecutions commenced by him, or by the Superintendent of Police, or by the Clerks of the Peace, at the Public instance" and, in such an event, the accused would have to be acquitted by the court.

16 Idem at 266-267.

17 See Ord 40 of 1828 (Regulating the Manner of Proceeding in Criminal Cases) (Cape).

18 Farlam \& Zimmermann 2001: 90.

19 Sections 1-5. 
The Attorney-General had the right, and was entrusted with the duty, to prosecute all offences committed in the colony. This right and duty to prosecute extended to all offences committed within the colony. This was presumably meant to provide, beyond a doubt, that no categories of offences were to be left to prosecution by private individuals. The Attorney-General had absolute power over prosecution. This meant, for example, that a private individual could not force him to prosecute an offence that he had declined to prosecute or to stop a prosecution that he had decided to pursue.

However, the Ordinance also provided for circumstances in which an individual might institute a private prosecution. Section 11 provided that "[w] here in virtue of the right of Prosecution hereinafter given to private Parties, any private Party intends to prosecute any Person" whose release from detention has been authorised by the Attorney-General, "it shall be competent for such private Parties, upon entering into a Recognizance for the Prosecution of the said Defendant in the form hereinafter set forth, to apply to the" relevant court or judicial officer (if the court is not sitting) "for a Warrant for the further detention in Gaol of such Person". The section further provided that, where the accused had already been released from detention "for his recommittal to" prison to await his trial and on the basis of that application, the court or judge "shall make such Order, as to them shall seem proper". It is important to note two things about section 11. First, it was possible for the "right of prosecution" to "be given to private parties". In other words, the Ordinance recognised that a private individual did not have an automatic right to institute a private prosecution. That right could only be granted if the Attorney-General had indicated that he was not going to prosecute the said person. Secondly, it was permissible for a private person to apply for a court order regarding the detention of a person he intended to prosecute.

Section 13 provided that:

In all cases, where the Public Prosecutor declines to prosecute for any alleged Crime or Offence, it is competent for any private Party, who alleges that he has suffered injury by any such alleged Crime or Offence, to prosecute in any Court, competent to the Trial of the same, the Person alleged to have committed such Crime or Offence.

Three things should be noted about section 13. First, a private individual could not institute a private prosecution unless the public prosecutor had declined to prosecute. This emphasised the fact that the public prosecutor had the right and duty to prosecute any offence committed in the colony. Secondly, a private prosecutor could prosecute "any alleged crime or offence". This meant that private prosecution was not limited to minor offences. Thirdly, for a private person to be able to institute a private prosecution, he must have allegedly "suffered injury" as a result of that offence. Put differently, he had to have been a victim of crime. 
Section 14 of the Ordinance stipulated as follows:

In order that no Prosecution, at the instance of a private Party, may take place, until the Public Prosecutor shall have exercised his discretion, whether he will prosecute the Offender at the Public instance, it shall not be competent for any private Party to obtain the Process of any Court for summoning any Party to answer to any Indictment or Complaint, unless the said private Party shall produce to the Officer, authorised by Law to issue such Warrant, the Indictment or Complaint, having endorsed thereon where the Indictment is to be tried in the Supreme or Circuit Court, a Certificate under the hand of, and subscribed by, the AttorneyGeneral, that he has seen the Indictment, and declines to prosecute at the Public instance for the Offence therein set forth; and where the Indictment or Complaint is to be tried in any Inferior Court, a Certificate, under the hand of, and subscribed by, the Officer who by Law is entitled to prosecute at the Public instance in such Court, that he has seen the said Indictment or Complaint, and declines to prosecute at the Public instance for the Offence therein set forth; and in every case, in which the Attorney-General declines to prosecute, he and the Officers, through whom he exercises the right of Prosecution in the Inferior Courts, shall, at the request of the Party intending to prosecute, grant the Certificates abovementioned on every Indictment submitted to them by such private Party.

Two aspects of section 14 are worth mentioning. First, a certificate from the Attorney-General or a public prosecutor was a prerequisite for any private party to institute a private prosecution. Without the certificate, the relevant court official could not issue the required court document to compel the accused to appear before court. ${ }^{20}$ Secondly, if the Attorney-General or his officer declined to prosecute, he had to ("shall") issue the relevant certificate to a person intending to institute a private prosecution. The word used here was "shall" and not "may". In other words, the moment the Attorney-General declined to prosecute, he had no choice but to issue the said certificate to a person who had applied for it. It was at that stage that the person could exercise his right to prosecute. The effect of this provision was that, once the Attorney-General had declined to exercise his duty and right to prosecute, the right to prosecute was bestowed on the victim of the crime. However, unlike the Attorney General, a victim of crime did not have a duty to prosecute.

Section 15 of the Ordinance provided that:

To support a Prosecution at the private instance, the private Party prosecuting must be able to show some substantial and peculiar interest in the issue of the Trial, arising out of some injury, which he individually has suffered by the commission of the alleged Crime or Offence set forth in the Indictment or Complaint.

20 In Mcunu v Landsberg (1913) 34 NPD 140, it was held that private prosecution was invalid if it was done without the certificate from the Attorney-General confirming that he had declined to prosecute. 
This section emphasised the fact that only victims of crime could institute private prosecutions. Nevertheless, under section 16, a husband possessed "this right of Prosecution in respect of Crimes and Offences committed against his wife". Also, in terms of section 17, "[t]he legal Guardians of Minors possess[ed] this right of Prosecution in respect of Crimes and Offences committed against their Wards". Section 18 furthermore provided that "[t]he Wife or Children, or where there is no Wife or Child, any of the next of kin, of any deceased Person, possess this right of Prosecution in respect of any Crime by which the Death of such Person is alleged to have been caused". It is critical to note that although a husband had a right to institute a private prosecution for an offence committed against his wife, a wife did not have a right to institute a private prosecution for an offence committed against her husband, unless the husband had died as a result of the alleged crime. This should be understood against the background that, at the time, equality between men and women did not exist. ${ }^{21}$ However, if a married woman was a public trader, she could institute a private prosecution against a debtor. ${ }^{22} \mathrm{~A}$ woman could also institute a private prosecution for offences committed against herself. ${ }^{23}$

Under section 19, in the event of an acquittal, a court was empowered to order a private prosecutor to reimburse the accused the expenses he had incurred defending himself. Section 20 required the private prosecutor to deposit $£ 20$ sterling at the court and to obtain two sureties before the court could summon the accused to be prosecuted. The British would later extend the above provisions on private prosecutions to other parts of South Africa. ${ }^{24}$

21 This means that s 7 of the 1977 Act, which still retains this discriminatory approach, is discriminatory against women and therefore unconstitutional. In Tsholo v Kgafela [2005] JOL 16146 (B), the widow instituted a private prosecution against a person who had allegedly murdered her husband on the basis of s 7 of the 1977 Act.

22 In Mcintyre v Goodison (1877) 7 Buch 83 at 84, the Supreme Court of the Cape of Good Hope held that "[i]n this particular case the [trade] license was made out in the name of the respondent; and we must, in the absence of evidence to the contrary, presume that she acted with the consent of her husband as a public trader". The court then quoted Van der Linden, who had stated that " $\mathrm{t}]$ he wife becomes, by marriage, as it were a minor; and the husband her curator or guardian: she has no power to appear in Court; she is not capable of herself to enter into any contract without the knowledge or consent of her husband, so as to bind her to others, except so far as she may clearly appear thereby to have derived an advantage or profit; or that she, with the knowledge of her husband, has carried on trade openly" and, again, where he stated that "[i]n like manner, when the cause concerns a married woman, the husband must appear for the wife, except in the following cases: 1 . When the woman is a public trader". The court therefore held that "inasmuch as this license was in the name of the woman herself, without the husband in any way being recognized or named in it, I think she has obtained a locus standi in matters appertaining to that license and business connected therewith, so as to entitle her to institute this private prosecution".

23 In Ex parte Hendley 1926 WLD 5, the Attorney-General granted a certificate that was used by the female applicant to institute a private prosecution for perjury.

24 Dugard 1977: 10-35. 
Apart from this criminal procedure Ordinance, other pieces of legislation passed in the nineteenth century also made provision for private prosecutions. These provided for two types of private prosecutions, namely those that could only be instituted by victims of crime ${ }^{25}$ and those that could be instituted by any person regardless of whether or not he had been a victim of crime. ${ }^{26}$ In those instances where more than one person was aggrieved by the commission of an offence, legislation required the Attorney-General to "select as private prosecutor the person whom he deems most fit and proper" to conduct the prosecution. ${ }^{27}$ In some instances, legislation provided that trustees could institute private prosecutions on behalf of organisations or societies. ${ }^{28}$ In 1830, the 1828 Ordinance was "explained" by way of a further Ordinance. The 1830 Ordinance stated that a certificate from the AttorneyGeneral was not a prerequisite for a person to institute a private prosecution under section 14, unless the offence in question was of such a nature that it "ought not to be permitted to be prosecuted at the instance of the private party". ${ }^{29}$ Although the 1830 Ordinance was amended in 1852, the amendments did not affect the provisions relating to the issue of the certificate in question. ${ }^{30}$ However, when the British later extended the law of criminal procedure to Natal and the Transvaal, they transplanted the 1828 Ordinance as it had been before the 1830 additions. ${ }^{31}$

The historical developments in South African law with regard to private prosecutions between 1828 and 1977 were succinctly summarised by the High Court in Black v Barclays Zimbabwe Nominees (Pvt) Ltd as follows: ${ }^{32}$

Apart from their substantial influence on legislation in the other provinces, the provisions of the Cape Ordinance of 1828 ... were to a large extent incorporated in the Criminal Procedure Act 31 of 1917. The subsequent Criminal Procedure Act 56 of 1955 substantially re-enacted the provisions of the 1917 Act relating to private prosecutions, the only relevant difference

25 See, for example, s 12 of the Cattle Theft Repression Act 16 of 1864 (Cape of Good Hope); 73 of Ord 6 of 1843 (Estates Insolvent) (Cape of Good Hope); and s 16 of the Stock and Produce Thefts Act 35 of 1893 (Cape of Good Hope).

26 See ss 8, 10 and 11 of the Corrupt Practices at Elections Prevention Act 21 of 1859 (Cape of Good Hope); s 22 of the Police Offences Act 27 of 1882 (Cape of Good Hope); s 9 of the Public Health Act 4 of 1883 (Cape of Good Hope); s XVI of the Wines and Spirits Act 8 of 1875 (Cape of Good Hope); s 17 of the Cruelty to Animals Law 31 of 1874 (Natal); and s 8 of the Sunday Law 24 of 1878 (Natal).

27 Section XVI of the Merchandise Marks Act 12 of 1864 (Cape of Good Hope).

28 Section 5 of the Friendly Societies' Act 7 of 1882 (Cape of Good Hope).

29 Sections 6 and 7 of Ord 73 of 1830 (Ordinance for Explaining, Altering, and Amending the Ordinance No 40) (Cape).

30 See Ord 8 of 1852 (Ordinance for Regulating in Certain Respects the Prosecution of Crimes in Districts in Which There Shall not Be Resident Clerks of the Peace, and for Other Purposes) (Cape of Good Hope).

31 Ord 18 of 1845 (Ordinance for Regulating the Manner of Proceeding in Criminal Cases in the District of Natal) (Natal); Ord 1 of 1903 (Criminal Procedure Code) (Transvaal).

32 Black v Barclays Zimbabwe Nominees (Pvt) Ltd 1990 (1) SACR 433 (W). 
between s 14 of the 1917 Act and s 11 of the 1955 Act being that the former referred to 'any private party' whereas the latter referred to 'any private person'. It is to be noted that there was no definition of the word 'party' in the then current Interpretation Act 5 of 1910. In the 1977 Act s 7 provides substantially the same as ss 11 and 14 of the 1955 Act. $^{33}$

The above extract from the judgement indicates that, like the Cape Ordinance of 1828, the Criminal Procedure and Evidence Act 31 of 1917 also provided for the right to institute a private prosecution. Section 14 of the latter Act provided that:

In all cases where the Attorney-General declines to prosecute for an alleged offence any private party, who can show some substantial and peculiar interest in the issue of the trial arising out of some injury which he individually has suffered by the commission of the offence, may prosecute in any court competent to try the offence, the person alleged to have committed it.

\section{Section 15 of the same Act provided that:}

The following also possess this right of prosecution: (a) A husband in respect of offences committed against his wife; (b) the legal guardians or curators of minors or lunatics in respect of offences committed against their wards; (c) the wife or children or, where there is no wife or child, any of the next of kin of any deceased person in respect of any offence by which the death of such person is alleged to have been caused; (d) public bodies and persons on whom the right is specially conferred by statute in respect of particular offences.

It is evident that the right to institute a private prosecution was expressly provided for in the 1917 Act. ${ }^{34}$ In Brown v Moffat, ${ }^{35}$ the court held that section 15 provided for the right of prosecution. In Thoppaya $v$ Kynochs, $L t d,{ }^{36}$ the court held that the phrasing in section 15(d) "must refer to a statutory provision which expressly gives the right to prosecute privately" ${ }^{37}$ The 1917 debates of the House of Assembly on the Criminal Procedure Bill show that the legislature was of the view that all prosecutions had to be conducted by the state and that private prosecutions were to be an exception. ${ }^{38}$

The Criminal Procedure and Evidence Act of 1917 was later replaced by the Criminal Procedure Act 56 of 1955. Unlike the 1917 Act, which expressly provided that victims of crime had a right to institute private prosecutions, this right was not expressly mentioned in the relevant section of the 1955 Act. ${ }^{39}$ Section 11 provided that:

33 Idem at 435-436.

34 See, also, s 16 of the 1917 Act, which expressly mentioned "the right of prosecution...given to private parties".

35 Brown v Moffat 1918 TPD 242 at 245.

36 Thoppaya v Kynochs, Ltd (1923) 44 NPD 341.

37 Idem at 349.

38 "Debates of the House of Assembly of the Union of South Africa as reported in the Cape Times, Volume II, Second Session, Second Parliament (16 February to 3 July 1917)" 3 Mar 1917 Cape Times at 43.

39 The Hansard version of the House of Assembly debate on the 1955 Criminal Procedure Bill is silent on the issue of private prosecutions. See Hansard Debates of the House of Assembly vols 87,88 and 89 at $1405-5161$. 
In any case in which the attorney-general declines to prosecute for an alleged offence: (a) any private person who proves some substantial and peculiar interest in the issue of the trial arising out of some injury which he individually suffered in consequence of the commission of the said offence; or (b) a husband, if the said offence was committed against his wife; or (c) the legal guardian or curator of a minor or lunatic, if the said offence was committed against his ward; or (d) the wife or child or, if there is no wife or child, any of the next of kin of any deceased person, if the death of such person is alleged to have been caused by the said offence, may, subject to the provisions of sections fourteen and fifteen prosecute in any court competent to try the said offence, the person alleged to have committed it.

Although section 11 does not expressly mention the right to institute a private prosecution, a reading of other relevant sections of the Act shows that section 11 could easily be interpreted as conferring on the victim of crime the right to institute a private prosecution. For example, section 1(xviii) defined a "private prosecutor" to mean "any public body or person who in terms of section eleven or twelve has the right to prosecute in respect of any offence". The right to institute a private prosecution was also referred to in sections $12^{40}$ and 15 of the Act. The 1955 Act was eventually replaced by the 1977 Act, which still applies today.

Unlike the 1917 Act, which expressly mentioned the right to institute a private prosecution on the basis of a certificate nolle prosequi, the 1977 Act does not expressly mention this right. Section 7 of the current Act provides that:

(1) In any case in which a Director of Public Prosecutions declines to prosecute for an alleged offence - (a) any private person who proves some substantial and peculiar interest in the issue of the trial arising out of some injury which he individually suffered in consequence of the commission of the said offence; (b) a husband, if the said offence was committed in respect of his wife; (c) the wife or child or, if there is no wife or child, any of the next of kin of any deceased person, if the death of such person is alleged to have been caused by the said offence; or (d) the legal guardian or curator of a minor or lunatic, if the said offence was committed against his ward, may, subject to the provisions of section 9 and section 59(2) of the Child Justice Act, 2008, either in person or by a legal representative, institute and conduct a prosecution in respect of such offence in any court competent to try that offence.

However, section 8 , which deals with "private prosecution under statutory right", provides that:

(1) Any body upon which or person upon whom the right to prosecute in respect of any offence is expressly conferred by law, may institute and conduct a prosecution in respect of such offence in any court competent to try that offence. (2) A body which or a person who intends exercising a right of prosecution under subsection (1), shall exercise such right only after consultation with the [DPP] concerned and after the [DPP] has withdrawn his right of

40 Section 12 provided that "[a]ny public body or any person on whom the right to prosecute in respect of any offence is expressly conferred by law, may prosecute in any court competent to try the said offence, the person alleged to have committed it". 
prosecution in respect of any specified offence or any specified class or category of offences with reference to which such body or person may by law exercise such right of prosecution. (3) A [DPP] may, under subsection (2), withdraw his right of prosecution on such conditions as he may deem fit, including a condition that the appointment by such body or person of a prosecutor to conduct the prosecution in question shall be subject to the approval of the [DPP], and that the [DPP] may at any time exercise with reference to any such prosecution any power which he might have exercised if he had not withdrawn his right of prosecution. ${ }^{41}$

It has been argued that a private prosecution under section 8 "is not a true 'private prosecution' even though it is identified as a 'private prosecution' in the Criminal Procedure Act". ${ }^{42}$ This is because these prosecutions are conducted by public bodies or authorities and they remain under the control of the DPP. For example, under section 6(b) of the current Act, a person or body conducting a prosecution under section 8 of the same Act cannot stop such a prosecution without the DPP's consent. The debates of the House of Assembly on the Criminal Procedure Bill, which would later become the 1977 Act, show that section 8 is not applicable to private prosecutions on the basis of a certificate nolle prosequi. One Member of Parliament argued that there was a need for Parliament to make it very clear that section 8 was only applicable to public bodies in order to avoid confusing private prosecutions on the basis of a certificate nolle prosequi and private prosecutions under statutory right. ${ }^{43}$ In response, the then Minister of Justice, who had tabled the Bill before Parliament, clarified that "this clause [clause 8] refers exclusively to bodies such as local authorities and other similar bodies that have the right to prosecute - nothing more". ${ }^{44}$ This means that the omission to expressly mention the right to institute a private prosecution under section 7 was not an oversight on the part of the legislature. The debates further indicate that prosecutions under section 8 are different from those under section $7 .{ }^{45}$

In the light of the above discussion, the question remains whether, under section 7 of the 1977 Act, a victim of crime has a right to institute a private prosecution on the basis of a certificate nolle prosequi. In order to answer this question in the next part of this contribution, reference will be made to case law and to the drafting history of section 7 .

41 Section 45 of the National Prosecuting Authority Act 32 of 1998 provides that "(a) an attorneygeneral shall, unless the context indicates otherwise, be construed as a reference to the National Director; and (b) an attorney-general or deputy attorney-general in respect of the area of jurisdiction of a High Court, shall be construed as a reference to a Director or Deputy Director appointed in terms of this Act, for the area of jurisdiction of that Court".

42 Joubert 2014: 84.

43 Hansard Debates of the House of Assembly (13 Apr 1973) cols 4811-4812 per submissions by Mr JJM Stephens.

44 Idem at col 4812 per submission by the Minister of Justice.

45 Hansard Debates of the House of Assembly (11 Mar 1977) cols 3393-3394. 


\section{The nature of the right to institute a private prosecution}

In contrast to the statutory position discussed above, the courts have long since recognised the right of a victim of crime to institute a private prosecution. This jurisprudence may be divided into two periods: the pre-1977 jurisprudence (when the right to institute a private prosecution was expressly provided for by the Criminal Procedure and Evidence Act 31 of 1917 and by its successor, the Criminal Procedure Act 56 of 1955); and the post-1977 jurisprudence, when this right is not expressly mentioned in the 1977 Act.

In the 1872 decision of Eaton v Moller, ${ }^{46}$ the Supreme Court of the Cape of Good Hope held that a victim of crime has a right to institute a private prosecution. ${ }^{47}$ In Chinian (Appellant) $v$ Kupusamy (Respondent), ${ }^{48}$ the court held that the relevant pieces of legislation "expressly declare the manner in which the right to a private prosecution may be established and exercised" ${ }^{49}$ In Wakefield (Appellant) $v$ Houghting (Respondent), ${ }^{50}$ the court held that "the right to prosecute has been conferred by law". ${ }^{51}$ As mentioned above, in Mullins and Meyer v Pearlman, ${ }^{52}$ the court held that "[t]he right of private prosecution for criminal offences in South Africa is apparently the creature of statute. It did not exist under Roman-Dutch law so far as I am aware". ${ }^{53}$ In 1949, the court referred to the right to institute a private prosecution as being "very special". ${ }^{54}$ In addition, it has been held that in case the

46 Eaton v Moller (1871-1872) 2 Roscoe 85.

47 See, also, Fischer $v$ Genricks (1885-1886) 4 SC 31, in which the court held that private prosecutions are authorised by legislation.

48 Chinian (Appellant) v Kupusamy (Respondent) (1892) 13 NLR 220.

49 Idem at 220.

$50 \quad$ Wakefield (Appellant) v Houghting (Respondent) (1895) 16 NLR 171

51 Idem at 173. See, also, Van Zijl v Graaf (1907) 24 SC 72 at 74, where the court stated that the rights of private prosecutors were governed by different pieces of legislation; and Mсипи v Landsberg (1913) 34 NPD 140 at 141, where the court held that the right to institute a private prosecution is governed by legislation.

52 Mullins and Meyer v Pearlman 1917 TPD 639.

53 Idem at 643. See, also, Thoppaya v Kynochs, Ltd (1923) 44 NPD 341 at 349. In Fourie v Resident Magistrate of Worcester (1897) 14 SC 54, the court held that "[b]y the common law of this country all criminal prosecutions must be conducted by a public prosecutor. A private individual, who under the Roman law had the right to prosecute in his own name, could in Holland only lay his complaint before the proper public official whose duty it became, upon sufficient cause shown, to conduct the prosecution on behalf of the State...[with reference to Voet]. In 1828, however, it was enacted in this [Cape] Colony, by Ord. No. 40, sect. 13, that where the public prosecutor declines to prosecute, it shall be competent for any private party, who alleges that he has suffered injury by any crime or offence, to prosecute the offender in any competent Court".

54 In Bornman v Van der Merwe 1946 OPD 192, the appellant was convicted as a result of a private prosecution by the respondent. The court held that "[e]ssentially, private prosecutions are in the nature of private litigation. The parties take their courage in both hands and institute and defend to gain their private ends. Since the State has made ample provision for the prosecution of offenders at the public instance, it seems equitable that the parties who desire to exercise their very special rights should do so at their own peril of being mulcted in costs. The same applies to the costs of appeal" (as quoted in Arenstein v Durban Corporation 1952 (1) SA 279 (A) at 300). 
DPP declines to prosecute or is prevented by the executive from issuing a certificate to allow a victim of crime to institute a private prosecution, the effect would be to deprive the victim of "a right to a "nolle prosequi". ${ }^{55}$ In such a case, a court will hold that the victim of crime has locus standi to institute a private prosecution even without a certificate nolle prosequi. This is because one of the objects of punishment is to prevent victims of crime from taking the law into their hands. ${ }^{56}$

In Freedom under Law v National Director of Public Prosecutions, ${ }^{57}$ the High Court held that "the right to pursue a private prosecution in terms of section 7" of the 1977 Act does not prevent courts from scrutinising a public prosecutor's decision not to prosecute. ${ }^{58}$ In Nundalal v Director of Public Prosecutions KZN,,$^{59}$ the High Court held that "[a] person whose feelings and good name are injured has the right to prosecute privately if he actaullay [sic] suffers an injury" ${ }^{\prime 60}$ and that "a decision to deny a private prosecutor the right to prosecute should be taken cautiously not least because it implicates the right to access to the court under s 34 of the Constitution. If he meets all the requirements for a private prosecution under the CPA and the right to prosecute is not hit by the limitation in s 36 , the private prosecution should be allowed to proceed" ${ }^{61}$ There are also other cases in which courts have mentioned a victim's right to conduct a prosecution under section 7 of the 1977 Act. ${ }^{62}$ However, the High Court has further observed that private prosecutions "are very rare in" South Africa. ${ }^{63}$

Apart from the fact that a private prosecution is a right, it can also be a remedy. ${ }^{64}$ The Constitutional Court has observed, in passing, that:

Whether a private prosecutor is exercising a governmental power is a point which need not now be decided. It may be argued that the private prosecutor is not vindicating a private right, but is invoking the power of the State to punish crime. Sections 12 and 13 of the Criminal Procedure Act 51 of 1977 reflect the State's continuing interest in a private prosecution. ${ }^{65}$

55 Mweuhanga v Cabinet of the Interim Government of South West Africa 1989 (1) SA 976 (SWA) at 984.

56 Shifidi v Administrator-General for South West Africa 1989 (4) SA 631 (SWA).

57 Freedom under Law v National Director of Public Prosecutions 2014 (1) SACR 111 (GNP).

58 Idem para 190.

59 Nundalal v Director of Public Prosecutions KZN2015 JDR 0876 (KZP).

$60 \quad$ Idem para 53.

61 Idem para 54.

62 Delport v S [2015] 1 All SA 286 (SCA) para 31; Reynolds NO v Beinash [1998] JOL 2274 (W) at 6; Black v Barclays Zimbabwe Nominees (Pvt) Ltd 1990 (1) SACR 433 (W) at 434 and 438.

63 Berg River Municipality v Zelpy 2065 (Pty) Ltd 2013 (4) SA 154 (WCC) para 47. See, also, Balagooroo Senaithalway Educational Trust v Soobramoney 1965 (3) SA 627 (N) at 629.

64 See Berg River Municipality v Zelpy 2065 (Pty) Ltd 2013 (4) SA 154 (WCC) para 47: "One would not usually regard a criminal remedy as one which is available to the harmed individual. It is a public remedy at the discretion of the prosecuting authorities. Only if the directorate of public prosecutions declines to prosecute can the individual launch a private prosecution, and I would hesitate to call a private prosecution an 'ordinary remedy'."

65 Du Plessis v De Klerk 1996 (5) BCLR 658 (CC) at n 88 
The above observation by the Constitutional Court is not without support. The drafting history of the sections on private prosecutions in the 1977 Act shows that one Member of Parliament was of the view that "a private prosecution is deemed to be on behalf of the State, but it is not at the instance of the State". ${ }^{66}$ In $S v D e$ Freitas,${ }^{67}$ the court held that:

[T] he right to institute a prosecution which is the right which lapses, is a right which vests in the State....and is a right which is exercised on behalf of the State by the Attorney-General [DPP]. Where the Attorney-General [DPP] declines to prosecute and issues a certificate nolle prosequi and where certain other requirements are present an interested member of the public is entitled to bring a private prosecution. The primary right, however, to prosecute is that of the State and at best the citizens with an interest have a spes which will only be realised in the event of the Attorney-General [DPP] declining to prosecute. ${ }^{68}$

In one case, the court held that the mere fact that the DPP has declined to prosecute does not mean that he is obliged to issue a certificate to the victim of crime to enable him to institute a private prosecution. ${ }^{69}$ Whether or not this view is correct, is doubtful.$^{70}$ However, the right to institute a private prosecution is not absolute and its limitations will be discussed below.

The discussion thus far shows that courts have held that a victim of crime has a right to institute a private prosecution under section 7 of the 1977 Act, even though section 7 does not expressly provide for that right. However, this holding is supported by the history of private prosecutions in South Africa. It should be noted that the 1996 Constitution refers to four categories of rights: (1) rights provided for in the Bill of Rights; (2) common-law rights; (3) customary law rights; and (4) statutory rights. ${ }^{71}$ In South African law, there is a clear distinction between commonlaw rights and statutory rights. ${ }^{72}$ However, as the Supreme Court of Appeal held, there is no "rule that a statutory right is stronger than a common-law right". ${ }^{73}$ It could be argued that in cases where the legislator's intention was to provide for a statutory right, this has been done expressly. For example, the 1977 Act provides for the the following rights: the right of statutory bodies to institute a private prosecution; ${ }^{74}$ the

66 Hansard Debates of the House of Assembly (11 Mar 1977) col 3394 per submissions by Mr WT Webber.

$67 S v$ De Freitas 1997 (1) SACR 180 (C).

68 Idem at 183.

69 Singh v Minister of Justice and Constitutional Development 2009 (1) SACR 87 (N).

70 See Nundalal v Director of Public Prosecutions KZN 2015 JDR 0876 (KZP).

71 Section 39(3) of the Constitution provides that " $[\mathrm{t}] \mathrm{he}$ Bill of Rights does not deny the existence of any other rights or freedoms that are recognised or conferred by common law, customary law or legislation, to the extent that they are consistent with the Bill".

72 Agri South Africa $v$ Minister for Minerals and Energy (Afriforum as amici curiae) 2013 (7) BCLR 727 (CC); Xstrata South Africa (Pty) Ltd v SFF Association 2012 (5) SA 60 (SCA) para 10.

73 Lester $v$ Ndlambe Municipality 2015 (6) SA 283 (SCA) para 23.

74 Section 8 of the Criminal Procedure Act 51 of 1977. 
right of the accused to institute bail proceedings ${ }^{75}$ the right of the accused to be tried before another judicial officer should the prosecutor and accused withdraw from the plea and sentence agreement; ${ }^{76}$ the right of the accused to legal representation; ${ }^{77}$ third-party rights in the property ordered to be forfeited to the state $;^{78}$ the right of complainants to make representations in some cases where the offender is being considered for parole; ${ }^{79}$ and the general right to prosecute. ${ }^{80}$

Although section 7 of the 1977 Act does not expressly provide for the right to institute a private prosecution, the drafting history of this section clearly shows that Parliament's intention was to provide for that right. The debates of the House of Assembly on the Criminal Procedure Bill indicates that Members of Parliament were of the view that section 7 provides for the right to institute a private prosecution. The submissions that "it is an important right of a private person to be able to prosecute privately" and that "[a]n ordinary private prosecutor prosecutes in respect of rights conferred upon him by this legislation, i.e. clause 7(1)" were not objected to ${ }^{81}$ The right to institute a private prosecute under section 7 of the 1977 Act is thus a statutory right.

In South African law, a victim of crime does not have a right to compel a public prosecutor to institute criminal proceedings against a suspected offender. ${ }^{82}$ In Gillingham v Attorney-General, ${ }^{83}$ the court held that it could not compel the Attorney-General to prosecute. Likewise, in Kuranda $v$ Barnet and Assistant Landdrost of Johannesburg, ${ }^{84}$ the court held that a public prosecutor may refuse to prosecute even if requested by a victim of crime to prosecute the suspect. However, this position is not unique to South Africa. ${ }^{85,86}$ In South Africa, although public prosecutors have the authority and a duty to prosecute crime, ${ }^{87}$ a public prosecutor

75 Idem s 50(1)(b).

76 Idem s $150 \mathrm{~A}(9)(\mathrm{d})$.

77 Idem s 73(2A).

78 Idem $\mathrm{s} 35$.

79 Idem s 299A Act. For cases in which this provision has been invoked, see Madonsela v $S$ [2014] ZAGPPHC 1013; Derby-Lewis v Minister of Correctional Services 2009 (6) SA 205 (GNP); S v Nxumalo [2018] JOL 40541 (KZD).

80 Section 18 of the Criminal Procedure Act 51 of 1977.

81 Hansard Debates of the House of Assembly (13 Apr 1973) cols 4811-4812 per submissions by $\mathrm{Mr}$ JJM Stephens.

82 Even the Service Charter for Victims of Crime in South Africa does not provide for this right. See Department: Justice and Constitutional Development (2004): passim.

83 Gillingham v Attorney-General 1909 TS 572.

84 (1891-1892) 4 SAR TS 288.

85 It is the same view as that held by the European Court of Human Rights. See, generally, Rainey, Wicks \& Ovey 2017: 289-290.

86 However, this position is not unique to South Africa. For example, the Nigerian Supreme Court held that "an individual has no right to insist that a criminal offence should be prosecuted by the State". See Attorney-General of Kaduna State v Mallam Umaru Hassan (1985) LPELRSC $149 / 1984$ at 26.

87 Glenister v President of the Republic of South Africa 2011 (3) SA 347 (CC) para 176. 
may in some circumstances decline to prosecute a suspect even if there is evidence that the latter committed an offence. ${ }^{88} \mathrm{~A}$ victim of crime who is not satisfied with the public prosecutor's decision not to prosecute has the following options: he may invoke section 179(5)(d) of the Constitution and petition the National Director of Public Prosecutions to review the decision not to prosecute ${ }^{89}$ he may institute a private prosecution; or he may approach the High Court and challenge the rationality, legality or lawfulness of the decision not to prosecute..$^{90}$ After illustrating the nature of the right to institute a private prosecution, it is important to have a look at some of the limitations to this right.

\section{$4 \quad$ Limitations on the right to institute a private prosecution}

The right to institute a private prosecution is not absolute. As already mentioned, this right only arises when the DPP has declined to prosecute. ${ }^{91}$ In the 1889 case of Himunchal, Appellant, $v$ Clerk of the Peace for Klip River, Respondent,${ }^{92}$ the court held that "there can be no private prosecution, until the Crown prosecutor has refused to prosecute, and his refusal has been certified on the plaint". ${ }^{93}$

There are situations where a victim of crime will not be permitted to institute a private prosecution against a person, even if there is evidence that that person committed the offence against the victim. These measures are perhaps meant to ensure that the right to institute a private prosecution is not abused. In South Africa, there have been attempts to abuse the right to institute private prosecutions.

88 See Freedom under Law v National Director of Public Prosecutions 2014 (1) SACR 111 (GNP) para 121 , where the court observes that " $[\mathrm{t}]$ he discretion of the prosecuting authority to prosecute, not to prosecute or to discontinue criminal proceedings is a wide one. Nonetheless, as is reflected in the Prosecution Policy Directives, the prosecuting authority has a duty to prosecute, or to continue a prosecution, if there is a prima facie case and if there is no compelling reason for nonprosecution".

89 Section 179(5)(d) of the 1996 Constitution provides that the National Director of Public Prosecutions "may review a decision to prosecute or not to prosecute, after consulting the relevant Director of Public Prosecutions and after taking representations within a period specified by the National Director of Public Prosecutions, from the following: (i) The accused person. (ii) The complainant. (iii) Any other person or party whom the National Director considers to be relevant".

90 See, generally, National Director of Public Prosecutions v Zuma 2009 (2) SA 277 (SCA); National Director of Public Prosecutions v Freedom under Law 2014 (4) SA 298 (SCA).

91 However, in Natal in earlier years, the Public Prosecutor did not have to decline to prosecute before a master could institute a private prosecution against his servant. See Himunchal $v$ Rojia (1904) 25 NLR 259. In the Transvaal, the Attorney-General's certificate was not required before a private prosecution could be instituted in a summary trial before an inferior court. See Rex v Japel 1906 TS 108.

92 Himunchal, Appellant, $v$ Clerk of the Peace for Klip River, Respondent (1889) 10 NLR 33.

93 Idem at 34. See, also, Thoppaya v Kynochs, Ltd (1923) 44 NPD 341 at 344. 
For example, in Van Deventer $v$ Reichenberg, ${ }^{94}$ the respondent instituted a private prosecution against the applicant, a Supreme Court judge, for allegedly defeating the ends of justice because he had set aside the respondent's earlier private prosecution. In making an order for the stay of prosecution, the court in casu held that it would be contrary to public policy for a judge to be cross-examined on a case he had presided over and that the respondent had abused court process by instituting a private prosecution.

In Ellis $v$ Visser, ${ }^{95}$ the private prosecutor did not have the title to institute a private prosecution, because he had no actionable injury. In Ernst \& Young $v$ Beinash, the court found that the respondent instituted a private prosecution without the title to prosecute and with ulterior motives. ${ }^{96}$ In Phillips $v$ Both $a,{ }^{97}$ the court found that a private prosecution had been instituted to enforce the payment of an illegal gambling debt. In Crookes $v$ Sibisi,$^{98}$ the court held that, like a public prosecutor, a private prosecutor is allowed to withdraw and reinstate a charge against the accused in terms of section 6(a) of the 1977 Act, and that a court will not allow a private prosecution to be used to harass the accused..$^{99}$ This is so, even though section 6(a) does not refer to private prosecutors. The High Court has held that "[n]otwithstanding that the private prosecutions are not strictly speaking civil proceedings, they are indeed forms of litigation that fall within the purview of the Vexatious Proceedings Act [3 of 1956$]$ ". ${ }^{100}$

Another way in which the abuse of the right to institute a private prosecution may be brought to an end, is by the DPP taking over the private prosecution. Section 13 of the 1977 Act provides that:

[A DPP] or a local public prosecutor acting on the instructions of the [DPP], may in respect of any private prosecution apply by motion to the court before which the private prosecution is pending to stop all further proceedings in the case in order that a prosecution for the offence in question may be instituted or, as the case may be, continued at the instance of the State, and the court shall make such an order.

The issue of whether or not a court may prevent the DPP from taking over a private prosecution under section 13 arose in the case of North Western Dense Concrete CC v Director of Public Prosecutions (Western Cape). ${ }^{101}$ The applicants had been

94 Van Deventer v Reichenberg 1996 (1) SACR 119 (C).

95 Ellis $v$ Visser 1954 (2) SA 431 (T).

96 Ernst \& Young v Beinash 1999 (1) SA 1114 (W) at 1135.

97 Phillips $v$ Botha 1999 (2) SA 555 (SCA).

98 Crookes $v$ Sibisi [2010] JOL 25407 (KZP).

99 Idem para 25. In $S v$ Hendrix 1979 (3) SA 816 (D) at 819, the court held that a private prosecutor may withdraw and reinstate a charge against an accused.

100 Ernst \& Young $v$ Beinash 1999 (1) SA 1114 (W) at 1135

101 North Western Dense Concrete CC v Director of Public Prosecutions (Western Cape) 1999 (2) SACR 669 (C). 
prosecuted with one $\mathrm{M}$. Following a plea agreement between $\mathrm{M}$ and the state, $\mathrm{M}$ pleaded guilty on condition that the charge against the applicants be withdrawn. When the charge against the applicants was withdrawn, one B, who had been the victim of the applicants' crime, applied for a certificate from the DPP to institute a private prosecution against the applicants. It is against that background that the respondent reinstated the charge against the applicants. He argued, inter alia, that "a Director of Public Prosecutions is obliged to institute a prosecution whenever a prima facie case is made out and a private person demands a certificate nolle prosequi". ${ }^{102}$ In ordering a stay of the applicants' prosecution, the court held that:

[I]t is open for a private individual to demand a certificate nolle prosequi from a Director and to proceed to institute a private prosecution, if he or she is aggrieved by the decision of that Director not to prosecute in any particular instance. Sections 7-15 of the Criminal Code allow therefor. The fact that these provisions of the Code were left unaffected by the legislator when it enacted the new Act indicate, in my view, that the legislator recognised that there would be instances where a prima facie case has been made out, but a Director of Public Prosecutions would exercise his discretion not to prosecute. In that recognition, the legislator elected not to interfere with that discretion, leaving the necessary avenues open for citizens aggrieved by perceived misapplication of that discretion to obtain redress. ${ }^{103}$

The court added that:

I have accordingly decided to grant an order in terms of which the prosecution of the first and second applicants is permanently stayed. In coming to this decision, I am mindful of the argument...that, were a private prosecution in due course to be instituted against the applicants, the respondent would be entitled, in terms of s 13 of the Code, to intervene and to take over the prosecution. In my view, the fact that this is so should not affect my decision. The respondent would have to apply to the court in which the prosecution is instituted in order to so intervene and, no doubt, would have to show cause why he should be allowed to so intervene. The order which I intend to grant will no doubt influence that court, when and if such an application is brought by the respondent. What that court decides, in the circumstances which may then prevail, cannot be predicted by me. ${ }^{104}$

In the above case, the court seems to suggest that in the DPP's application to take over a private prosecution, he has to show cause why he or she should intervene; failing that, the application may be rejected. There are at least three reasons why the court's interpretation of section 13 above is disputable. First, section 13 provides that once an application is brought, the court has no alternative but to allow the DPP to intervene. The word used is "shall" as opposed to "may." The drafting history of the 1977 Act shows that Parliament was of the view that when the word "shall" is used, "the court is obliged" to do what the section in question requires. ${ }^{105}$ The DPP

102 Idem at 680-681.

103 Idem at 680 .

$104 \mathrm{Idem}$ at 684 .

105 Hansard Debates of the House of Assembly (13 Apr 1973) cols 4817-4824. Although the majority view was that, in practice, “'may' means nothing else but 'shall'. Every magistrate will interpret the 'may' as 'shall'" (at 4824). 
does not even have to consult with the private prosecutor. Secondly, the drafting history of section 13 shows that the intention of the legislature was to make it clear that the DPP was not to seek the court's permission before taking over a private prosecution. ${ }^{106}$ Thirdly, earlier jurisprudence does not support the court's reasoning. This jurisprudence makes it clear that neither the court, nor the private prosecutor can stop the DPP from taking over a private prosecution. In Central African Examiner (Pvt) Ltd v Howman NNO, ${ }^{107}$ the court held that "the Court has no power to stop him prosecuting at the public instance if he wishes to do so, except on the basis that the issue is res judicata", ${ }^{108}$ and that should the DPP decide to take over a private prosecution "the Court has no discretion to refuse to allow him to do so". ${ }^{109}$

What is not clear in section 13 is whether the DPP may take over a private prosecution for the purpose of stopping it. Section 13 appears to suggest that the DPP can only intervene in a private prosecution for the sole purpose of continuing it at the instance of the state. However, since section 6 of the 1977 Act empowers the DPP to discontinue a prosecution, nothing prevents him from discontinuing a private prosecution that he has taken over. This is because the moment the DPP takes over a private prosecution, it becomes a public prosecution. It should also be remembered that section 20(1)(c) of the National Prosecuting Authority Act 32 of 1998 empowers a public prosecutor to discontinue criminal proceedings. ${ }^{110}$ One of the ways in which the victim's right may be strengthened is for the court to have the discretion to decide whether or not to allow the DPP's application to intervene in a private prosecution, and for the private prosecutor to then consent to the DPP's application. This approach has been taken in countries, such as the Gambia ${ }^{111}$ and Ghana. ${ }^{112}$

The question remains whether, under section 6 of the 1977 Act, the private prosecutor or the court has a role to play before the DPP stops a private prosecution that he has taken over. Section 6 of the 1977 Act provides that:

A [DPP] or any person conducting a prosecution at the instance of the State or any body or person conducting a prosecution under section 8 , may (a) before an accused pleads to a charge, withdraw that charge, in which event the accused shall not be entitled to a verdict of acquittal in respect of that charge; (b) at any time after an accused has pleaded, but before conviction, stop the prosecution in respect of that charge, in which event the court trying the accused shall acquit the accused in respect of that charge: Provided that where a prosecution is conducted by a person other than [the DPP] or a body or person referred to in section 8 , the prosecution shall not be stopped unless the [DPP] or any person authorized thereto by the [DPP], whether in general or in any particular case, has consented thereto.

106 Idem at cols 4812-4813.

107 Central African Examiner (Pvt) Ltd v Howman NNO [1966] 2 All SA 260 (R).

108 Idem at 265.

109 Idem at 266.

110 For the discussion of the relationship between s 6 of the Criminal Procedure Act 51 of 1977 and s 20(1)(c) of the National Prosecuting Authority Act 32 of 1998, see Freedom under Law v National Director of Public Prosecutions 2014 (1) SACR 111 (GNP) paras 157-160.

111 Sections 85-86 of the Constitution of the Republic of Gambia 1 of 1997.

112 Section 56 of the Constitution of the Republic of Ghana, 1992. 
In simple terms, these are some of the observations about section 6 of the 1977 Act. First, the section contemplates that only three types of people may conduct the prosecution in question, namely: the DPP; any person conducting a prosecution at the instance of the state (public prosecutor); and any body or person conducting a prosecution in terms of section 8 . Secondly, in stopping a prosecution, the DPP does not need anyone's consent. However, a public prosecutor (who is not the DPP) or any body or person conducting a prosecution on the basis of section 8 needs the DPP's consent to stop a prosecution. The question of whether section 6 is applicable to both public and private prosecutions arose during the debates in the National Assembly. One legislator, Mr Webber, asked the Minister of Justice:

$[\mathrm{T}] \mathrm{o}$ explain the intention of the proviso...that provides that...if the prosecution is at the instance of a person other than an Attorney-General or a body or person referred to in section 8 , i.e. a statutory body, such trial shall not be stopped unless the Attorney-General has consented. Is it the intention of the hon. the Minister and of this legislation that any prosecutor in any court who...wishes to stop a trial after the accused has pleaded...shall first obtain the approval of the Attorney-General? ${ }^{113}$

In response, the Minister submitted that the above proviso "applies only to private prosecutions and statutory provisions of the municipalities. In other words, if a court case is already in progress, the trial shall be stopped in consultation with the Attorney-General". ${ }^{114}$ It was submitted that if the Minister's argument, namely that the proviso referred to private prosecutions on the basis of a certificate nolle prosequi, was correct, "then he should do away with this proviso, because as clause 6 reads at the moment, there is no reference whatsoever to a private prosecution". ${ }^{115}$ The Member added that clause 6 is not applicable to private prosecutors, but that it only applies to state prosecutors. ${ }^{116}$ The Minister responded that he was "not prepared to accept the" proposed amendment, but that he "shall have another look at it, and if it proves to be necessary" he was willing to make the amendment. ${ }^{117}$ The Hansard debates $^{118}$ and the text of section 6 show that the Minister did not find it necessary to make the amendment.

This means that there are two possible ways to interpret section 6(b). The first interpretation is that it is only applicable to public prosecutors and prosecutors conducting prosecutions on the basis of section 8 of the 1977 Act. This reading is supported by the submissions by Mr Webber and by the literal meaning of the section. It is also the reading supported by some South African authors, ${ }^{119}$ prosecutors and

113 Hansard Debates of the House of Assembly (11 Mar 1977) col 3393.

114 Idem at 3393.

115 Idem at 3394.

116 Ibid.

117 Ibid.

118 Idem at 3394-4530.

119 Joubert 2014: 74. 
courts. ${ }^{120}$ The second interpretation is that it is applicable to private prosecutions. This reading is based on the Minister's submissions in Parliament. In the author's opinion, the text of section 6 shows that it is applicable to public prosecutors only.

\section{Locus standi to institute a private prosecution}

As mentioned above, a victim of crime may institute a private prosecution. ${ }^{121}$ Section 10 of the 1977 Act provides that a private prosecution has to be instituted in the name of the private prosecutor. ${ }^{122}$ This enables the accused to know, inter alia, whether or not he will pay the costs of the prosecution in the event of a successful prosecution. ${ }^{123}$ A private prosecution may be instituted in respect of any offence. In Lemue $v$ Zwartbooi, ${ }^{124}$ the court held that "a private party who has suffered injury by any crime or offence may...prosecute where the public prosecutor has declined to prosecute". ${ }^{125}$ In other words, a person who has been injured by the commission of an offence has a right and is "entitled" to institute a private prosecution. ${ }^{126}$ The 1977 Act does not require that a private prosecutor should have a prima facie case against the accused before he may institute a private prosecution, and the High Court has not questioned this position. ${ }^{127}$

An issue which has been dealt with by South African courts concerns whether a private company may institute a private prosecution. South African courts have held that a private company is not a "private person" within the meaning of section 7 of

$120 S v$ Gouws 2008 (2) SACR 640 (T); S v Soli [2000] JOL 7171 (Ck); S v Tom; S v Barnard [2010] JOL 24827 (ECG); $S$ v Sethoga [1990] 1 All SA 292 (A); S v Magayela [2003] JOL 11566 (T); Gneiting v $S$ [2006] JOL 17437 (T); S v Masilo [2017] JOL 38866 (FB).

121 See Hansard Debates of the House of Assembly (13 Apr 1973) col 4806, where it is stated that, in most cases, the private prosecutor will be the original complainant.

122 See Claymore Court (Pty) Ltd v Durban City Council 1986 (4) SA 180 (N); and the much older case of Latchmenna $v$ Regina (1899) 20 NLR 185.

123 Queen $v$ Wicks (1897-1898) 12 EDC 98 at 100.

124 Lemue v Zwartbooi (1896) 13 SC 403.

125 Idem at 406.

126 Queen v Mitchell (1897) 14 SC 119 at 121.

127 In Solomon v Magistrate, Pretoria 1950 (3) SA 603 (T) at 613, the court held that "[t]he Legislature...must have contemplated that private prosecutors might in many cases have weak grounds for prosecution - a decision by the [DPP] not to prosecute would indicate this - but the policy of Parliament, no doubt, was to allow prosecution even in weak cases, in order to avoid the taking of the law by the complainant into his own hands. The Act contains no provision requiring that the private prosecutor shall satisfy anyone that he has a prima facie case. The penalty for vexatious and unfounded prosecution is liability for costs". Nevertheless, historically, a private prosecution could only be instituted once the High Court had established that the private prosecutor had a prima facie case against the accused. In other words, in addition to the certificate from the Attorney-General that he had declined to prosecute (which he had to issue without concerning himself with the question of whether or not a private prosecutor had a prima facie case), the High Court had to grant permission to the private prosecutor to prosecute. See Ex parte Andrews (1908) 22 EDC 336; Daly v The Solicitor-General 1911 EDL 399; Ex Parte Cole 1914 EDL 399. 
the 1977 Act and therefore has no locus standi to institute a private prosecution. ${ }^{128}$ In Black v Barclays Zimbabwe Nominees (Pvt) Ltd, ${ }^{129}$ the court referred to the history of the legislative provisions on private prosecutions in South Africa and held that:

\begin{abstract}
It would appear from the aforegoing that the right to prosecute privately was originally created for natural persons only, viz people affected by offences in the manner contemplated in the relevant provisions. Companies incorporated by registration...had not yet made their appearance on the community scene at that time. The first legislation concerning companies in the Cape Colony was the Joint Stock Companies Limited Liability Act 23 of 1861 which was followed by the Cape Companies Act 25 of 1892, the latter being replaced by the Companies Act 46 of 1926 and which applied in South Africa until the Companies Act 61 of 1973 was promulgated. ${ }^{130}$
\end{abstract}

On appeal, the Appellate Division (now the Supreme Court of Appeal) agreed with the High Court that private companies are not permitted to institute private prosecutions under section 7 of the 1977 Act. The Appellate Division added that:

The general policy of the Legislature is that all prosecutions are to be public prosecutions in the name and on behalf of the State...The exceptions are firstly where a law expressly confers a right of private prosecution upon a particular body or person (these bodies and persons being referred to in $\mathrm{s} 8(2)$ ) and, secondly, those persons referred to in $\mathrm{s} 7$. There may well be sound reasons of policy for confining the right of private prosecution to natural persons as opposed to companies, close corporations and voluntary associations such as, for example, political parties or clubs. ${ }^{131}$

Other courts have since held that private companies do not have locus standi to institute private prosecutions. ${ }^{132}$ Although courts have referred to section 7 to hold that juristic persons are not permitted to institute private prosecutions, the history of private prosecutions in South Africa shows that an argument could still be made that section 7 does not prohibit juristic persons from instituting private prosecutions. Two reasons will be advanced in support of this submission. First, the drafting history of section 7 does not show reasons why the right to institute a private prosecution should not be extended to private companies. The debates of the House of Assembly on the Criminal Procedure Bill, which would later become the 1977 Act, show that not even a single Member of Parliament submitted that private companies should not

128 Black v Barclays Zimbabwe Nominees (Pvt) Ltd 1990 (1) SACR 433 (W).

129 Ibid.

130 Idem at 436.

131 Barclays Zimbabwe Nominees (Pvt) Ltd v Black 1990 (4) SA 720 (A) at 726. However, in the past, a bank could institute a prosecution. See, for example, s 4 of the Natal Bank Law 43 of 1888. A railway company could also prosecute: see s 18 of the Stanger and Kearsney Railway Act 40 of 1899 (Natal).

132 Reynolds NO v Beinash [1998] JOL 2274 (W); National Society for the Prevention of Cruelty to Animals v Minister of Justice and Constitutional Development (Corruption Watch as amicus curiae) 2017 (4) BCLR 517 (CC). 
be permitted to institute private prosecutions. ${ }^{133}$ If one of the objectives of section 7 was to prevent private companies from instituting private prosecutions, one would have expected the legislature to expressly provide for that. Secondly, and perhaps most importantly, there is evidence that private companies have indeed instituted private prosecutions in certain instances after the Attorneys-General had declined to prosecute. This is so, notwithstanding the fact that South African legislation has never expressly authorised private companies to institute private prosecutions. For example, in Mosenthal \& Co $v$ Cantor, ${ }^{134}$ the court permitted private companies to conduct a private prosecution against the accused for fraudulent insolvency, and these companies went ahead to conduct the private prosecutions. In Thoppaya $v$ Kynochs, $L t d,{ }^{135}$ the court did not question the right of a private company to institute a private prosecution. ${ }^{136}$ In Joseph Baynes, Ltd $v$ The Minister of Justice, ${ }^{137}$ the Attorney-General declined to prosecute one Lawson for theft (he had stolen money from the applicant company). The applicant, a private company, instituted a private prosecution against Mr Lawson and he was convicted. The magistrate, and later the High Court, ordered the state to pay the costs that the applicant company had incurred in prosecuting Mr Lawson. The above judgements show that there is evidence that private companies have instituted private prosecutions in the past.

A director, shareholder or creditor of a company has no locus standi to institute a private prosecution on behalf of a company. This is because a company is a distinct entity from its shareholders, directors and creditors and an offence committed against the company is not committed against its shareholders, directors or creditors. ${ }^{138}$ This could explain why some private companies have made funds available to the National Prosecuting Authority to prosecute people who have committed offences

133 Hansard Debates of the House of Assembly (13 Apr 1973) cols 4805-4812.

134 Mosenthal \& Co v Cantor 1915 EDL 371. The indictment on which the court based its decision stated that "William Mosenthal, Edgar Adolph Henry Mosenthal and Harold Robert Mosenthal (carrying on business in partnership as Adolph Mosenthal \& Co.), merchants, of Port Elizabeth, and Stephen Fraser \& Co., merchants, of Port Elizabeth, prosecuted Barnett Cantor, a shopkeeper, formerly of Steytlerville, now of Cape Town, on the following charges: (1) Fraudulent insolvency in that whereas his estate was sequestrated as insolvent on December 22, 1914, he did between November 11, 1914, and January 18, 1915, at Steytlerville, Port Elizabeth, and other places unknown to the prosecutors, conceal and remove $£ 76819 \mathrm{~s}$. 1d. (part of his estate) with intent to defraud his creditors; and (2) Culpable insolvency, in that while carrying on business as a shopkeeper at Steytlerville he failed, from and after September 10, 1914, to keep reasonable books and accounts".

135 Thoppaya $v$ Kynochs, Ltd (1923) 44 NPD 341.

136 See, for example, Mosenthal \& Co v Cantor 1915 EDL 371, where the court granted the applicants (including private companies) permission to prosecute a person for fraud. See, also, Thoppaya $v$ Kynochs, Ltd (1923) 44 NPD 341, in which the court did not question the right of a private company to institute a private prosecution.

137 Joseph Baynes, Ltd $v$ The Minister of Justice 1926 TPD 390

138 Reynolds v Beinash [1998] JOL 2274 (W). 
against these companies. This is on the basis of section 38 of the National Prosecuting Authority Act 32 of $1998 .{ }^{139}$

In one case, the court found that although prima facie it seemed like a public prosecution, it was in fact a private prosecution masquerading as a public prosecution. ${ }^{140}$ There may be a need for South Africa to amend its legislation so that private companies are expressly empowered to institute private prosecutions. This is because private companies, like natural persons, are also affected by crime ${ }^{141}$ and they have been working closely with the South African government in the fight against crime. Most importantly, some of these companies are willing and able to finance the prosecution of those who have committed crimes against them. It has to be recalled that the fact that a private company prosecutes those who have committed offences against it does not mean that the accused will not get a fair trial. As early as 1846, the law provided that a private prosecutor can be a witness in a case he is prosecuting. ${ }^{142}$ Section 35(3) of the Constitution guarantees the accused a right to a fair trial, irrespective of whether the prosecutor is a private prosecutor or a public prosecutor. Furthermore, the Constitutional Court held that an accused in a private prosecution has the same rights as an accused in a public prosecution. ${ }^{143}$ In Citibank NAv Van Zyl NO, ${ }^{144}$ the High Court held that "in a private prosecution in terms of section 7 of the Criminal Procedure Act 51 of 1977, the onus and standard of proof do not differ from those applicable to a prosecution by the State". ${ }^{145}$ Failure to amend section 7 of the 1977 Act to expressly allow private companies to institute private prosecutions means, inter alia, that its constitutionality will be challenged. In the past, the constitutionality of section 7 was already challenged on the ground that it unfairly discriminates against juristic persons. However, the Constitutional Court,

139 Section 38 provides that "(1) The National Director may in consultation with the Minister, and a Deputy National Director or a Director may, in consultation with the Minister and the National Director, on behalf of the State, engage, under agreements in writing, persons having suitable qualifications and experience to perform services in specific cases. (2) The terms and conditions of service of a person engaged by the National Director, a Deputy National Director or a Director under subsection (1) shall be as determined from time to time by the Minister in concurrence with the Minister of Finance. (3) Where the engagement of a person contemplated in subsection (1) will not result in financial implications for the State - (a) the National Director; or (b) a Deputy National Director or a Director, in consultation with the National Director, may, on behalf of the State, engage, under an agreement in writing, such person to perform the services contemplated in subsection (1) without consulting the Minister as contemplated in that subsection. (4) For purposes of this section 'services' include the conducting of a prosecution under the control and direction of the National Director, a Deputy National Director or a Director, as the case may be".

140 Bonugliv Deputy National Director of Public Prosecutions 2010 (2) SACR 134 (T); Sv Tshotshoza 2010 (2) SACR 274 (GNP).

141 See South African Police Service "Annual crime report" (2017/2018) available at https://www. saps.gov.za/services/annual_crime report2019.pdf> (accessed $24 \mathrm{Jul} 2019$ ).

142 Section 5 of Ord 14 of 1846 (Ordinance for Improving the Law of Evidence) (Cape) provided that "no person shall hereafter be incompetent to give evidence in any case by reason that in such case he prosecutes at his own instance for any crime or offence".

143 See Bothma v Els 2010 (1) BCLR 1 (CC).

144 Citibank NA v Van Zyl NO [2008] JOL 21103 (O).

145 Idem para 16. 
because of the unique facts of the case it was dealing with, did not find it necessary to resolve the issue of whether or not section 7 was unconstitutional. ${ }^{146}$

\section{Persons against whom a private prosecution may not be instituted}

There are persons against whom a private prosecution may not be instituted. Section 59(2) of the Child Justice Act 75 of $2008^{147}$ provides that "a private prosecution in terms of section 7 of the Criminal Procedure Act may not be instituted against a child in respect of whom the matter has been diverted in terms of this Act". A private prosecution may also not be instituted against a person who has been indemnified from prosecution. In Rapholo $v$ State President, ${ }^{148}$ the court held that " $[t]$ he option of a private prosecution in terms of s 7 of the Criminal Procedure Act...is a useful safety valve in the absence of which parties might take the war-path. This right is lost where indemnity is granted". ${ }^{149}$ This is also the case where a witness incriminates himself/herself as a state witness in terms of section 204 of the 1977 Act. In addition, previous legislation from 1830 also provided that a private prosecution could not be brought against an accomplice who had given evidence for the prosecution. ${ }^{150}$ However, a person may institute a private prosecution against his spouse. ${ }^{151}$

\section{Cost to institute private prosecution and security by a private prosecutor}

In terms of section 15 of the 1977 Act, a private individual has to incur the expenses associated with conducting a private prosecution. ${ }^{152}$ This has required

146 National Society for the Prevention of Cruelty to Animals $v$ Minister of Justice and Constitutional Development (Corruption Watch as amicus curiae) 2017 (4) BCLR 517 (CC).

147 Child Justice Act 75 of 2008.

148 Rapholo $v$ State President 1993 (1) SA 680 (T).

149 Idem at 688-689.

150 See s 10 of Ord 72 of 1830 (Ordinance for Altering, Amending, and Declaring in Certain Respects, the Law of Evidence within this Colony) (Cape).

151 Rohloffv Ocean Accident and Guarantee Corporation Ltd 1960 (2) SA 291 (A) at 302.

152 Section 15 provides that "(1) The costs and expenses of a private prosecutor shall, subject to the provisions of subsection (2), be paid by the private prosecutor. (2) The court may order a person convicted upon a private prosecution to pay the costs and expenses of the prosecution, including the costs of any appeal against such conviction or any sentence: Provided that the provisions of this subsection shall not apply with reference to any prosecution instituted and conducted under section 8: Provided further that where a private prosecution is instituted after the grant of a certificate by an attorney-general [DPP] that he declines to prosecute and the accused is convicted, the court may order the costs and expenses of the private prosecution, including the costs of an appeal arising from such prosecution, to be paid by the State". There is an exception to this principle. Section 182 of the Criminal Procedure Act 51 of 1977 provides that "[a] prisoner who is in a prison shall be subpoenaed as a witness on behalf of the defence or a private prosecutor only if the court before which the prisoner is to appear as a witness authorizes that the prisoner be subpoenaed as a witness, and the court shall give such authority only if it is satisfied that the evidence in question is necessary and material for the defence or the private prosecutor, as the case may be, and that the public safety or order will not be endangered by the calling of the witness". 
private individuals to instruct attorneys and advocates to conduct prosecutions on their behalf. ${ }^{153}$ This is the case, even though section 7(1) of the 1977 Act allows a private prosecutor to conduct a private prosecution "either in person or by a legal representative". The debates of the House of Assembly on the Criminal Procedure Bill show that Members of Parliament were of the view that in many instances private prosecutors would need legal advice and representation in instituting and conducting private prosecutions. ${ }^{154}$ Over a hundred years ago, the court highlighted the need for legal assistance in conducting private prosecutions. In Fourie v Resident Magistrate of Worcester, ${ }^{155}$ the court held that " $[t]$ he obstacles in the way of a private prosecution are so great that it is impossible to expect a private and unlettered individual successfully to encounter them without legal assistance". ${ }^{156}$

Also, section 9 of the 1977 Act provides that a private prosecutor has to deposit an amount as security that he will prosecute the offence expeditiously and also as security for the costs that may be incurred in respect of the accused's defence to the charge. In the combined cases of In re JN Fuller's Insolvent Estate; and JN Fuller (Applicant) $v$ Trustees (Respondents), ${ }^{157}$ the court held that "in a private prosecution, the prosecutor is bound to give security to pay costs". ${ }^{158}$ There are thus two deposits to be made in terms of section 9. The first deposit is the one to ensure that the prosecutor will prosecute the matter expeditiously. In the author's opinion, there is no objection to this deposit, provided the amount in question is not exorbitant or negligible. If the amount is exorbitant, it might discourage low-income-earning victims of crime from instituting private prosecutions. If it is negligible, it might encourage those who do not have a genuine desire to prosecute offenders in the shortest time possible to institute private prosecutions. However, the second deposit (as security for the costs that the accused may incur in his defence) might impede low-income-earning victims of crime from instituting private prosecutions if the alleged offender is a wealthy person who engages the services of expensive lawyers. This is what happened, for example, in the case of Du Toit $v$ Rooiberg Mineral Development Co, Ltd. ${ }^{159}$ In this case, the appellant instituted a private prosecution against the respondent company for alleged victimisation. The appellant engaged the services of a junior counsel to prosecute the respondent. The respondent company instructed an expensive law firm to defend it, and the firm then instructed a senior counsel, junior counsel and an attorney. The magistrate ordered the appellant to deposit an amount proposed by the respondent company's lawyers. The appellant

153 Bonadei v Magistrate of Otjiwarongo 1986 (1) SA 564 (SWA).

154 Hansard Debates of the House of Assembly (13 Apr 1973) cols 4807-4810.

155 Fourie v Resident Magistrate of Worcester (1897) 14 SC 54.

156 Idem at 60 .

157 In re JN Fuller's Insolvent Estate (1883) 4 NLR 14; JN Fuller (Applicant) v Trustees (Respondents) 1883 NPD 14.

158 Idem at 15.

159 Du Toit v Rooiberg Mineral Development Co, Ltd 1954 (1) SA 297 (T). 
appealed against this order to the High Court arguing, inter alia, "that the magistrate, though he realised that his decision made it impossible for the appellant to institute the private prosecution gave appellant no alternative decision which would enable him to institute the same". ${ }^{160}$ The appellant further added "that no reasonable person would have fixed the amount of security at a figure so high as to amount for all practical purposes to a nullification of the appellant's right of private prosecution". ${ }^{161}$ In dismissing the appeal, the High Court held that a magistrate's order on the issue of security deposit is not appealable to the High Court and that "the fact that his determination of the amount of the security, if otherwise unexceptionable, has the unfortunate consequence of making a private prosecution by appellant a matter of practical impossibility, show that the magistrate's determination was in any way irregular or unreasonable". ${ }^{162}$ In Williams v Janse Van Rensburg (1), ${ }^{163}$ the court held that the private prosecutor was not required to make a deposit, because the accused's legal bill was to be footed by the state. The court held that "the words "costs which the accused may incur' in $\mathrm{s} 9(1)$ (b) mean costs which the accused will probably incur personally or, to put it another way, the costs referred to are those which an accused might reasonably be expected to bear personally". ${ }^{164}$ Although a victim of crime has a right to institute a private prosecution, such proceedings can be an expensive exercise. This fact has been recognised by South African courts for many years. In Jamalodien $v$ Ajimudien, ${ }^{165}$ the court observed that incurring expenses in conducting a private prosecution "is unavoidable". ${ }^{166}$ One hundred years later, in Ndlovu $v S,{ }^{167}$ the Constitutional Court likewise observed that "instituting a private prosecution is prohibitively expensive". ${ }^{168}$ In effect, this means that it is only the wealthy who can exercise the right to institute a private prosecution. Low-income earners may not be able to exercise this right unless they fundraise or unless they are assisted by non-governmental organisations. ${ }^{169}$ However, section 15(2) of the 1977 Act provides that, in the event of a successful private prosecution, a court may order the convicted person or the state to pay the costs and expenses of the private prosecution. Case law

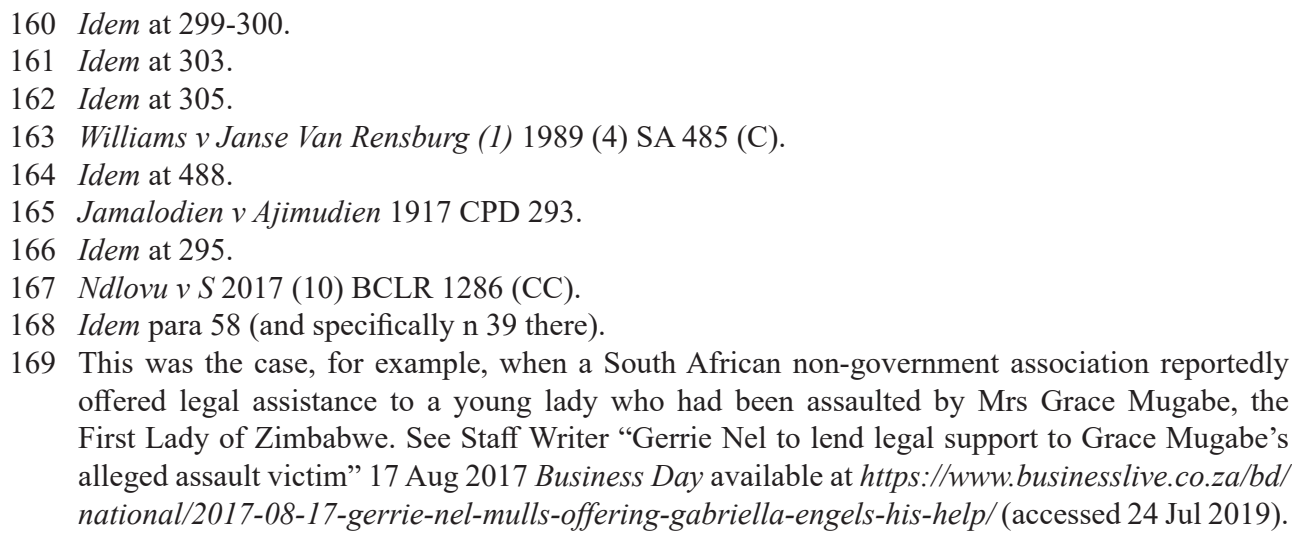

169 This was the case, for example, when a South African non-government association reportedly offered legal assistance to a young lady who had been assaulted by Mrs Grace Mugabe, the First Lady of Zimbabwe. See Staff Writer "Gerrie Nel to lend legal support to Grace Mugabe's alleged assault victim" 17 Aug 2017 Business Day available at https://www.businesslive.co.za/bd/ national/2017-08-17-gerrie-nel-mulls-offering-gabriella-engels-his-help/(accessed 24 Jul 2019). 
shows that an application has to be made by the private prosecutor before a court may order the state to pay the costs of a private prosecution. ${ }^{170}$

\section{Costs in the event of an unsuccessful private prosecution}

Section 16 of the 1977 Act provides that:

(1) Where in a private prosecution, other than a prosecution contemplated in $\mathrm{s} 8$, the charge against the accused is dismissed or the accused is acquitted or a decision in favour of the accused is given on appeal, the court dismissing the charge or acquitting the accused or deciding in favour of the accused on appeal, may order the private prosecutor to pay to such accused the whole or any part of the costs and expenses incurred by him in connection with the prosecution or, as the case may be, the appeal. (2) Where the court is of the opinion that a private prosecution was unfounded and vexatious, it shall award to the accused at his request such costs and expenses incurred by him as it may deem fit.

In Carter, Appellant, $v$ Alexander, Respondent, ${ }^{171}$ the court held that "costs are given in private prosecutions in like manner as in civil cases". ${ }^{172}$ In a private prosecution, a court can only award those costs that are authorised by law. ${ }^{173}$ The court has held that "a private prosecutor runs the risk of an adverse order of costs". ${ }^{174}$ In Buchanan $v$ Voogt $N O,{ }^{175}$ the court held that its power under section 16(1) is discretionary and that section $16(2)$ is peremptory. ${ }^{176}$ The court added that:

A prerequisite to the application of the provisions of ss (2) is that the prosecution has been, in the opinion of the court, unfounded and in addition, vexatious. That is clearly the effect of the use of the conjunctive 'and' between 'unfounded' and 'vexatious'. Subsection (2) confers a discretion on the court as to when a prosecution is to be characterised as unfounded and vexatious but it is a judicial discretion which is subject to review. ${ }^{177}$

The court further held that "the court should be slow in coming to a decision mulcting in costs under that subsection a prosecutor who bona fide seeks justice in a private

170 In Greyling $v$ Tunce 1920 EDL 1, the respondent was convicted of assault with intent to cause murder on the basis of a private prosecution instituted by the applicant after a certificate had been granted by the Solicitor General. The court ordered the state to pay the costs and expenses that the applicant had incurred in prosecuting the respondent. See, also, Joseph Baynes, Ltd v The Minister of Justice 1926 TPD 390, in which the court held that the magistrate had been correct when he had ordered the state to pay the costs and expenses that the applicant company had incurred in prosecuting the accused for theft.

171 Carter, Appellant, v Alexander, Respondent (1884) 5 NLR 288.

172 Idem at 290.

173 Snyders $v$ Theron (1892-1893) 10 SC 309.

174 Buchanan v Marais NO 1991 (2) SA 679 (A) at 685.

175 Buchanan v Voogt NO 1988 (2) SA $273(\mathrm{~N})$.

176 Idem at 274.

177 Ibid. 
prosecution". ${ }^{178}$ However, if it is clear that a private prosecution was instituted when the private prosecutor knew that the prosecution was unfounded and then still went ahead with it, he opens himself not only to civil action, but may also be ordered to pay the accused's costs. ${ }^{179}$ In other words, in deciding whether or not to order the private prosecutor to pay the costs and expenses incurred by the acquitted person, courts will consider the reason behind, and the circumstances surrounding, the institution of a private prosecution. ${ }^{180}$

\section{Conclusion}

In this article, the author has dealt with the history of the right to institute private prosecutions in South Africa. The author suggests ways through which this right may be strengthened. There may be a need for the law to be amended to empower private companies to institute private prosecutions. The existence of the right to institute a private prosecution has enabled victims of crime to participate in the criminal justice system. This has resulted in ensuring that some perpetrators, who would otherwise have escaped punishment, are brought to book for the offences they have committed. ${ }^{181}$ This right has also been used by some organisations to put pressure on the National Prosecuting Authority to prosecute influential individuals whom public prosecutors had, for questionable reasons, decided not to prosecute. ${ }^{182}$ In situations where the legislation establishing a statutory body is vague on the question of whether or not such a body may institute private prosecutions against people for

178 Idem at 275. In Boopa v Magistrate, Lion's River 1931 NPD 179, in which the accused was acquitted in a private prosecution, the court refused to order the private prosecutor to pay the applicant the costs and expenses incurred in defending himself.

179 In $R v$ Chipo 1953 (3) SA 602 (SR) at 611, the court held that "[o]ur system of public prosecution places obstacles in the way of anyone who wants his neighbour to be prosecuted on a charge which he knows to be false, chief among them being the requirement that the Attorney-General or his deputy shall determine whether there are good grounds for prosecution before any prosecution, whether public or private, can be instituted. If in spite of these obstacles any such false informant persists in a private prosecution he makes himself liable, not only to a civil action, but also to be mulcted in costs".

180 Maree v Bidder, NO 1939 CPD 437.

181 A few years ago, a case was reported in the media in which a father successfully instituted a private prosecution against a man who murdered his daughter (the private prosecutor's daughter). See "Girlfriend-killer found guilty in private prosecution" $10 \mathrm{Jul} 2014$ News 24 available at $h t t p s: / / w w w$. news24.com/SouthAfrica/News/Girlfriend-killer-found-guilty-in-private-prosecution-20140710 (accessed 3 Nov 2017).

182 Mathope "AfriForum's Gerrie Nel to prosecute Duduzane Zuma privately for the 2014 crash" 17 Oct 2017 Citizen available at https://citizen.co.za/news/south-africa/1692265/afriforums-gerrienel-to-prosecute-duduzane-zuma-privately-for-the-2014-crash/ (accessed 24 Jul 2019); Grobler "One charge of culpable homicide withdrawn against Duduzane Zuma" 26 Mar 2019 News24 available at https://www.news24.com/SouthAfrica/News/second-charge-of-culpable-homicidewithdrawn-against-duduzane-zuma-20190326 (accessed 24 Jul 2019). 
allegedly mistreating animals, the Constitutional Court interpreted that legislation so as to indeed permitting the statutory body to institute private prosecutions. ${ }^{183}$ This serves to show that the Constitutional Court is aware of the critical role that private prosecutors may play in the protection of animals against cruelty. The same judgement also shows that there is a possibility that anti-corruption activists could, in the near future, petition the Constitutional Court to interpret section 7 of the 1977 Act in such a manner that would empower them, and in particular juristic persons, to institute private prosecutions against government officials for allegedly committing economic crimes, such as corruption and money laundering. ${ }^{184}$ For example, an international oil giant was also convicted of environmental offences in South Africa by way of private prosecution. ${ }^{185}$

That said, one of the questions that has to be addressed is whether the private prosecution procedure in South Africa is an effective remedy available to victims of crime. ${ }^{186}$ In Salisbury Bottling Co (Pvt) Ltd v Central African Bottling Co (Pvt) $L t d,{ }^{187}$ the court referred to the legislation governing private prosecutions on the basis of a certificate nolle prosequi and held that " $[t]$ his procedure by private prosecution can therefore provide an effective remedy to a private person in cases in which the breach of a statutory duty is made a criminal offence". ${ }^{188}$ As mentioned above, in Berg River Municipality v Zelpy 2065 (Pty) Ltd, ${ }^{189}$ the court observed that private prosecution is a remedy, albeit not an ordinary one. A private prosecution may be instituted for different objectives, including the need to ensure that perpetrators of crime are brought to book for the offences they have committed. It is also one of the ways in which a victim of crime participates in the criminal justice system. However, the challenge remains that although there is a possibility of instituting a private prosecution, it is very unlikely that the poor will be able to institute such proceedings. This is because of the costs and expenses associated with such prosecutions. A crime will almost always involve the violation of the victim's right or rights. This means

183 National Society for the Prevention of Cruelty to Animals v Minister of Justice and Constitutional Development 2017 (4) BCLR 517 (CC).

184 Idem paras 3, 22, 23 and 64.

185 Uzani Environmental Advocacy CC v BP Southern Africa (Pty) Ltd [2019] JOL 41717 (GP).

186 International human rights bodies require the existence of effective remedies in states parties to different treaties. See, for example, Human Rights Committee "Concluding observations on the third periodic report of Bosnia and Herzegovina" CCPR/C/BIH/CO/3 (13 Apr 2017) para 8; Human Rights Committee "Concluding observations on the third periodic report of Serbia" CCPR/C/ $\mathrm{SRB} / \mathrm{CO} / 3$ (10 Apr 2017) para 17; Committee on the Elimination of Discrimination against Women "Concluding observations on the eighth the Protection of the Rights of All periodic report of Ukraine" CEDAW/C/UKR/CO/8 (9 Mar 2017) para 11(d); Committee on the Protection of the Rights of All Migrant Workers and Members of their Families "Concluding observations on the initial report of Honduras" CMW/C/HND/CO/1 (3 Oct 2016) para 39.

187 Salisbury Bottling Co (Pvt) Ltd v Central African Bottling Co (Pvt) Ltd [1958] 2 All SA 204 (FC).

188 Idem at 211.

189 Berg River Municipality v Zelpy 2065 (Pty) Ltd 2013 (4) SA 154 (WCC) para 47. 
that instituting a private prosecution is one of the ways to ensure that a victim of crime protects his rights. It is therefore imperative that stumbling blocks are not put in the victim's way in protecting his rights through private prosecution. Below are some of the strategies that could be adopted to ensure that the right of a victim of crime to institute a private prosecution is strengthened.

There is a need to ensure that indigent private prosecutors get state funding to conduct these prosecutions. This issue was raised over a hundred years ago by the Supreme Court of the Cape of Good Hope in the case of Fourie v Resident Magistrate of Worcester ${ }^{190}$ where the court held that:

In my opinion the privilege to conduct a private prosecution implies the right to appear in Court by Counsel or agent. It would in many cases be a useless privilege if the law were otherwise. An ignorant person is charged with an offence and convicted. He subsequently discovers evidence which proves to his satisfaction that the conviction was obtained on perjured evidence. He may not in the first instance be able to induce the public prosecutor to take the same view of the case, but in order to lay his case properly before the Magistrate with a view to a committal of the alleged offenders for trial he wishes to be assisted in Court by his legal adviser...In the absence of any express prohibition by law I am of opinion that the right to appear by agent must be held to exist. ${ }^{191}$

The court expressly held that a private prosecutor has a right to be represented by counsel if he is to exercise his right to institute a private prosecution meaningfully. Another way to strengthen the right to institute a private prosecution is to amend the 1977 Act to require that, in case the DPP has declined to prosecute, the police or the public prosecutor should make available all the relevant evidence in their possession to the private prosecutor. The law could also provide that the police or the public prosecutor may decline to make such evidence available to the private prosecutor if there are compelling reasons to do so. The drafting history of private prosecutions in terms of section 7 of the 1977 Act supports this recommendation. During the debates in Parliament on the Criminal Procedure Bill, one of the reasons given as to why the period within the certificate nolle prosequi should expire if not used should be increased from six weeks to six months (although it was later increased to three months), was that "[t]here may be difficulties in issuing the process within so short a period of time, bearing in mind that it may be necessary for the person instituting the private prosecution to obtain documents which were previously in the hands of the State". ${ }^{192}$ This implies that the DPP, should he decline to prosecute, is expected to make available to the private prosecutor the relevant documents or other evidence in his possession. A private prosecutor could also rely on section 32 of the Constitution.

190 Fourie v Resident Magistrate of Worcester (1897) 14 SC 54.

191 Idem at 59.

192 Hansard Debates of the House of Assembly (13 Apr 1973) col 4805. 
JAMIL DDAMULIRA MUJUZI

\section{Bibliography}

Committee on the Elimination of Discrimination against Women "Concluding observations on the eighth periodic report of Ukraine” CEDAW/C/UKR/CO/8 (9 Mar 2017)

Committee on the Protection of the Rights of All Migrant Workers and Members of Their Families "Concluding observations on the initial report of Honduras" CMW/C/HND/CO/1 (3 Oct 2016)

"Debates of the House of Assembly of the Union of South Africa as reported in the Cape Times, Volume II, Second Session, Second Parliament (16 February to 3 July 1917)" 3 Mar 1917 Cape Times

Department: Justice and Constitutional Development (2004) "Service charter for victims of crime in South Africa" available at http://www.justice.gov.za/VC/docs/vc/vc-eng.pdf (accessed 24 Jul 2019)

Dugard, John (1977) South African Criminal Law and Procedure vol 4 Introduction to Criminal Procedure (Cape Town)

Farlam, Paul \& R Zimmermann (2001) "South Africa (Report 1)" in Palmer, VV (ed) Mixed Jurisdictions Worldwide: The Third Legal Family (Cambridge): 83-144

"Girlfriend-killer found guilty in private prosecution" $10 \mathrm{Jul} 2014$ News24 available at https://www.news24.com/SouthAfrica/News/Girlfriend-killer-found-guilty-in-privateprosecution-20140710 (accessed 3 Nov 2017)

Grobler, Riaan "One charge of culpable homicide withdrawn against Duduzane Zuma" 26 Mar 2019 News24 available at https://www.news24.com/SouthAfrica/News/second-charge-ofculpable-homicide-withdrawn-against-duduzane-zuma-20190326 (accessed 24 Jul 2019)

Hansard Debates of the House of Assembly (21 Jan-23 Jun 1955)

Hansard Debates of the House of Assembly (11 Mar 1977)

Hansard Debates of the House of Assembly (13 Apr 1973)

Hansard UK House of Commons Debates no 7 (25 Jul 1822) col 1801 available at https://api. parliament.uk/historic-hansard/commons/1822/jul/25/commission-of-inquiry (accessed 11 Apr 2019)

Human Rights Committee "Concluding observations on the third periodic report of Bosnia and Herzegovina” CCPR/C/BIH/CO/3 (13 Apr 2017)

Human Rights Committee "Concluding observations on the third periodic report of Serbia" CCPR/C/SRB/CO/3 (10 Apr 2017)

Joubert, JJ (ed) (2014) Criminal Procedure Handbook 12 ed (Cape Town)

Mathope, Gosebo “AfriForum's Gerrie Nel to prosecute Duduzane Zuma privately for the 2014 crash" 17 Oct 2017 Citizen available at https://citizen.co.za/news/south-africa/1692265/ afriforums-gerrie-nel-to-prosecute-duduzane-zuma-privately-for-the-2014-crash/ (accessed 24 Jul 2019)

Rainey, Bernadette, E Wicks \& C Ovey (2017) Jacobs, White and Ovey: The European Convention on Human Rights 7 ed (Oxford)

South African Police Service "Annual crime report" (2017/2018)" available at https://www.saps. gov.za/services/annual_crime_report2019.pdf(accessed 24 Jul 2019) 
Staff Writer "Gerrie Nel to lend legal support to Grace Mugabe's alleged assault victim” 17 Aug 2017 Business Day available at https://www.businesslive.co.za/bd/national/2017-08-17gerrie-nel-mulls-offering-gabriella-engels-his-help/(accessed 24 Jul 2019)

Theal, George McCall (1897) Records of the Cape Colony 1793-1831 vol 21 (London)

Van den Bergh, Rena (2012) "The remarkable survival of Roman-Dutch Law in nineteenthcentury South Africa" Fundamina 18(1): 71-90

Van Niekerk, Gardiol (2015) "Multilingualism in South African courts: The legislative regulation of language in the Cape during the nineteenth century" Fundamina 21(2): 372-391

\section{Legislation}

\section{South Africa}

Cattle Theft Repression Act 16 of 1864 (Cape of Good Hope)

Child Justice Act 75 of 2008

Constitution of the Republic of South Africa, 1996

Corrupt Practices at Elections Prevention Act 21 of 1859 (Cape of Good Hope)

Criminal Procedure and Evidence Act 31 of 1917

Criminal Procedure Act 51 of 1977

Criminal Procedure Act 56 of 1955

Cruelty to Animals Law 31 of 1874 (Natal)

Extension of Security of Tenure Act 62 of 1997

Foodstuffs, Cosmetics and Disinfectants Act 54 of 1972

Friendly Societies' Act 7 of 1882 (Cape of Good Hope)

Hazardous Substances Act 15 of 1973

Merchandise Marks Act 12 of 1864 (Cape of Good Hope)

Natal Bank Law 43 of 1888 (Natal)

National Environmental Management Act 107 of 1998

National Prosecuting Authority Act 32 of 1998

Ord 1 of 1903 (Criminal Procedure Code) (Transvaal)

Ord 6 of 1843 (Estates Insolvent) (Cape of Good Hope)

Ord 8 of 1852 (Ordinance for Regulating in Certain Respects the Prosecution of Crimes in Districts in Which There Shall not Be Resident Clerks of the Peace, and for Other Purposes) (Cape of Good Hope)

Ord 14 of 1846 (Ordinance for Improving the Law of Evidence) (Cape)

Ord 18 of 1845 (Ordinance for Regulating the Manner of Proceeding in Criminal Cases in the District of Natal) (Natal)

Ord 40 of 1828 (Regulating the Manner of Proceeding in Criminal Cases) (Cape)

Ord 72 of 1830 (Ordinance for Altering, Amending, and Declaring in Certain Respects, the Law of Evidence within this Colony) (Cape) 
Ord 73 of 1830 (Ordinance for Explaining, Altering, and Amending the Ordinance No 40) (Cape) Police Offences Act 27 of 1882 (Cape of Good Hope) Public Health Act 4 of 1883 (Cape of Good Hope) Stanger and Kearsney Railway Act 40 of 1899 (Natal) Stock and Produce Thefts Act 35 of 1893 (Cape of Good Hope) Sunday Law 24 of 1878 (Natal)

Wines and Spirits Act 8 of 1875 (Cape of Good Hope)

\section{Other jurisdictions}

Constitution of the Republic of Gambia 1 of 1997

Constitution of the Republic of Ghana, 1992

\section{Table of cases}

\section{South Africa}

Agri South Africa v Minister for Minerals and Energy (Afriforum as amici curiae) 2013 (7) BCLR 727 (CC)

Arenstein v Durban Corporation 1952 (1) SA 279 (A)

Balagooroo Senaithalway Educational Trust v Soobramoney 1965 (3) SA 627 (N)

Barclays Zimbabwe Nominees (Pvt) Ltd v Black 1990 (4) SA 720 (A)

Benoni Municipality v Jungi Ragnana 1956 (3) SA 513 (T)

Berg River Municipality v Zelpy 2065 (Pty) Ltd 2013 (4) SA 154 (WCC)

Black v Barclays Zimbabwe Nominees (Pvt) Ltd 1990 (1) SACR 433 (W)

Bonadei v Magistrate of Otjiwarongo 1986 (1) SA 564 (SWA)

Bonugli v Deputy National Director of Public Prosecutions 2010 (2) SACR 134 (T)

Boopa v Magistrate, Lion's River 1931 NPD 179

Bornman v Van der Merwe 1946 OPD 192

Bothma v Els 2010 (1) BCLR 1 (CC)

Brown v Moffat 1918 TPD 242

Buchanan v Marais NO 1991 (2) SA 679 (A)

Buchanan v Voogt NO 1988 (2) SA 273 (N)

Carter, Appellant, v Alexander, Respondent (1884) 5 NLR 288

Central African Examiner (Pvt) Ltd v Howman NNO [1966] 2 All SA 260 (R)

Chinian (Appellant) v Kupusamy (Respondent) (1892) 13 NLR 220

Citibank NA v Van Zyl NO [2008] JOL 21103 (O)

Claymore Court (Pty) Ltd v Durban City Council 1986 (4) SA 180 (N)

Crookes v Sibisi [2010] JOL 25407 (KZP) 
Cuppa Gownden (Appellants) v Hawksworth (Respondent) (1896) 17 NLR 340

Daly $v$ The Solicitor-General 1911 EDL 399

Delport $v$ S [2015] 1 All SA 286 (SCA)

Derby-Lewis v Minister of Correctional Services 2009 (6) SA 205 (GNP)

Du Plessis v De Klerk 1996 (5) BCLR 658 (CC)

Du Toit v Rooiberg Mineral Development Co, Ltd 1954 (1) SA 297 (T)

Eaton v Moller (1871-1872) 2 Roscoe 85

Ellis v Visser 1954 (2) SA 431 (T)

Ernst \& Young $v$ Beinash 1999 (1) SA 1114 (W)

Ex parte Andrews (1908) 22 EDC 336

Ex parte Cole 1914 EDL 399

Ex parte Hendley 1926 WLD 5

Fischer v Genricks (1885-1886) 4 SC 31

Fourie v Resident Magistrate of Worcester (1897) 14 SC 54

Freedom under Law v National Director of Public Prosecutions 2014 (1) SACR 111 (GNP)

Germiston Town Council v Union Government 1931 TPD 396

Gillingham v Attorney-General 1909 TS 572

Glenister v President of the Republic of South Africa 2011 (3) SA 347 (CC)

Gneiting $v$ S [2006] JOL 17437 (T)

Greyling v Tunce 1920 EDL 1

Groenewoud and Colyn v Innesdale Municipality 1915 TPD 413

Himunchal v Rojia (1904) 25 NLR 259

Himunchal, Appellant, $v$ Clerk of the Peace for Klip River, Respondent (1889) 10 NLR 33

In re JN Fuller's Insolvent Estate (1883) 4 NLR 14; JN Fuller (Applicant) v Trustees (Respondents) 1883 NPD 14

Jamalodien v Ajimudien 1917 CPD 293

Joseph Baynes, Ltd v The Minister of Justice 1926 TPD 390

Kuranda v Barnet and Assistant Landdrost of Johannesburg (1891-1892) 4 SAR TS 288

Latchmenna $v$ Regina (1899) 20 NLR 185

Lemue v Zwartbooi (1896) 13 SC 403

Lester v Ndlambe Municipality 2015 (6) SA 283 (SCA)

Madonsela v $S$ [2014] ZAGPPHC 1013

Maree v Bidder, NO 1939 CPD 437

Mcintyre v Goodison (1877) 7 Buch 83

Mcunu v Landsberg (1913) 34 NPD 140

Mosenthal \& Co v Cantor 1915 EDL 371

Mullins and Meyer $v$ Pearlman 1917 TPD 639

Mweuhanga $v$ Cabinet of the Interim Government of South West Africa 1989 (1) SA 976 (SWA) 
National Director of Public Prosecutions v Freedom under Law 2014 (4) SA 298 (SCA)

National Director of Public Prosecutions v Zuma 2009 (2) SA 277 (SCA)

National Society for the Prevention of Cruelty to Animals $v$ Minister of Justice and Constitutional Development (Corruption Watch as amicus curiae) 2017 (4) BCLR 517 (CC)

Ndlovu v 2017 (10) BCLR 1286 (CC)

North Western Dense Concrete CC v Director of Public Prosecutions (Western Cape) 1999 (2) SACR 669 (C)

Nundalal v Director of Public Prosecutions KZN [2015] ZAKZPHC 28

Phillips v Botha 1999 (2) SA 555 (SCA)

Queen v Mitchell (1897) 14 SC 119

Queen v Wicks (1897-1898) 12 EDC 98

$R v$ Chipo 1953 (3) SA 602 (SR)

Rapholo v State President 1993 (1) SA 680 (T)

Rex v Japel 1906 TS 108

Rex v Kupeka 1929 OPD 65

Reynolds $v$ Beinash [1998] JOL 2274 (W)

Rohloff v Ocean Accident and Guarantee Corporation Ltd 1960 (2) SA 291 (A)

$S v$ De Freitas 1997 (1) SACR 180 (C)

Sv Gouws 2008 (2) SACR 640 (T)

$S v$ Hendrix 1979 (3) SA 816 (D)

$S v$ Magayela [2003] JOL 11566 (T)

$S v$ Masilo [2017] JOL 38866 (FB)

Sv Nxumalo [2018] JOL 40541 (KZD)

Sv Sethoga [1990] 1 All SA 292 (A)

Sv Soli [2000] JOL 7171 (Ck)

Sv Tom; $S$ v Barnard [2010] JOL 24827 (ECG)

Sv Tshotshoza 2010 (2) SACR 274 (GNP)

Salisbury Bottling Co (Pvt) Ltd v Central African Bottling Co (Pvt) Ltd [1958] 2 All SA 204 (FC)

Shifidi v Administrator-General for South West Africa 1989 (4) SA 631 (SWA)

Singh v Minister of Justice and Constitutional Development 2009 (1) SACR 87 (N)

Snyders $v$ Theron (1892-1893) 10 SC 309

Solomon v Magistrate, Pretoria 1950 (3) SA 603 (T)

The King $v$ Levey (1905) 19 EDC 167; Levey $v$ Bayes 1905 EDL 167

Thoppaya $v$ Kynochs, Ltd (1923) 44 NPD 341

Tsholo v Kgafela [2004] ZANWHC 36

Uzani Environmental Advocacy CC v BP Southern Africa (Pty) Ltd [2019] JOL 41717 (GP)

Van Deventer v Reichenberg 1996 (1) SACR 119 (C)

Van Zijl v Graaf (1907) 24 SC 72 
THE HISTORY AND NATURE OF THE RIGHT TO INSTITUTE A PRIVATE PROSECUTION

Wakefield (Appellant) v Houghting (Respondent) (1895) 16 NLR 171

Williams v Janse Van Rensburg (1) 1989 (4) SA 485 (C)

Woolf v Rex 1911 EDL 119

Xstrata South Africa (Pty) Ltd v SFF Association 2012 (5) SA 60 (SCA)

\section{Other jurisdictions}

Attorney-General of Kaduna State v Mallam Umaru Hassan (1985) LPELR-SC 149/1984 